\title{
MARGRA Lamb Eating Quality and Human Health-Promoting Omega-3 Long-Chain Polyunsaturated Fatty Acid Profiles of Tattykeel Australian White Sheep: Linebreeding and Gender Effects
}

\author{
Shedrach Benjamin Pewan ${ }^{1,2}{ }^{(}$, John Roger Otto ${ }^{1}\left(\mathbb{D}\right.$, Robert Tumwesigye Kinobe ${ }^{1}{ }^{(D}$, \\ Oyelola Abdulwasiu Adegboye ${ }^{3(1)}$ and Aduli Enoch Othniel Malau-Aduli $1, *$ (D) \\ 1 Animal Genetics and Nutrition, Veterinary Sciences Discipline, College of Public Health, Medical and \\ Veterinary Sciences, Division of Tropical Health and Medicine, James Cook University, \\ Townsville, QLD 4811, Australia; shedrach.pewan@my.jcu.edu.au (S.B.P.); john.otto@jcu.edu.au (J.R.O.); \\ robert.kinobe@jcu.edu.au (R.T.K.) \\ 2 National Veterinary Research Institute, Private Mail Bag 01 Vom, Plateau State, Nigeria \\ 3 Australian Institute of Tropical Health and Medicine, College of Public Health, Medical and \\ Veterinary Sciences, Division of Tropical Health and Medicine, James Cook University, \\ Townsville, QLD 4811, Australia; oyelola.adegboye@jcu.edu.au \\ * Correspondence: aduli.malauaduli@jcu.edu.au; Tel.: +61-747-815-339
}

Received: 16 October 2020; Accepted: 11 November 2020; Published: 12 November 2020

check for updates

\begin{abstract}
Health-conscious consumers increasingly demand healthier, tastier, and more nutritious meat, hence the continuous need to meet market specifications and demand for high-quality lamb. We evaluated the longissimus dorsi muscle of 147 Tattykeel Australian White (TAW) sheep fed on antioxidant-rich ryegrass pastures exclusive to MAGRA lamb brand for meat eating quality parameters of intramuscular fat (IMF) content, fat melting point (FMP) and omega-3 long-chain polyunsaturated fatty acids (n-3 LC-PUFA). The aim was to assess the impact of linebreeding and gender on pasture-fed lamb eating quality and to test the hypothesis that variation in healthy lamb eating quality is a function of lamb gender and not its antioxidant status or inbreeding coefficient (IC). After solid-phase extraction and purification, phenolics and antioxidant enzyme activities were analysed by high-performance liquid chromatography and mass spectrometry. IMF and fatty acid composition were determined using solvent extraction and gas chromatography, respectively. IC was classified into low $(0-5 \%)$, medium $(6-10 \%)$ and high (>10\%) and ranged from $0-15.6 \%$. FMP and IMF ranged from 28 to $39^{\circ} \mathrm{C}$ and $3.4 \%$ to $8.2 \%$, with overall means of $34.6 \pm 2.3^{\circ} \mathrm{C}$ and $4.4 \pm 0.2 \%$, respectively, and n-3 LC-PUFA ranged from "source" to "good source" levels of 33-69 mg/100 g. Ewes had significantly $(P<0.0001)$ higher IMF, C22:5n-3 (DPA), C22:6n-3 (DHA), C18:3n-6, C20:3, C22:4n-6, C22:5n-6, total monounsaturated (MUFA), PUFA and $\Sigma \mathrm{n}-3$ fatty acids and lower total saturated fatty acids (SFA) and FMP, than rams. As IC increased, there were no differences in FMP and IMF. Folin-Ciocalteu total phenolics, ferric reducing antioxidant power and antioxidant activities of glutathione peroxidase, catalase and superoxide dismutase enzymes did not differ by either gender or IC. This study provides evidence that IC is inconsequential in affecting antioxidant status, IMF, FMP and n-3 LC-PUFA in linebred and pasture-fed TAW sheep because the observed variation in individual fatty acids was mainly driven by gender differences between ewes and rams, hence the need to accept the tested hypothesis. This finding reinforces the consistent healthy eating quality of MARGRA lamb brand from TAW sheep regardless of its linebred origin.
\end{abstract}

Keywords: antioxidants; Tattykeel Australian White; MARGRA lamb; meat quality; longissimus dorsi muscle; omega-3 LC-PUFA; fat melting point; intramuscular fat; inbreeding coefficient; gender 


\section{Introduction}

The Food and Agriculture Organisation (FAO) of the United Nations defines meat quality as the constitutional standard of lean-to-fat ratio and palatability indices that include visual appearance, aroma, drip loss, colour, texture, $\mathrm{pH}$, intramuscular fat content, fatty acid and fat melting point profiles, tenderness, flavour and juiciness [1]. Meat and Livestock Australia (MLA) describes the entire processes of feeding culminating in the finishing of animals including their genetic constitution, husbandry practices and handling, as all affect the overall quality of meat [2]. Fat melting point (FMP), intramuscular fat (IMF) content (marbling) and fatty acid (FA) profile all influence eating quality and, ultimately, consumer preferences for consistent, safe, nutritious and tasty lamb with a healthy FA composition [3]. Globally, meat is regarded as one of the main sources of animal protein [4,5] and lamb is known to be highly nutritious and digestible [6], fortified with essential amino acids, iron, zinc, selenium, fatty acids and vitamins A, B6 and B12 [5]. Lamb also has relatively low lipid and saturated fat contents compared to meat from other ruminants [7], and its marbling, tenderness, juiciness, aroma and colour attributes have been known to influence consumer liking [8], carcass [9], meat assignment into quality grades [10], consumer food choices [11] and nutritional value [12]. It is therefore very important that sheepmeat producers guarantee the consistency of their lamb products in order to meet consumer preferences and adapt to the dynamics of purchasing decisions based on meat eating quality.

FMP dictates fat firmness. Soft fat has a low melting point and vice versa [13]. From a nutritional perspective, fats with low melting points consist of high levels of unsaturated fatty acids, and, conversely, fats with high melting points have comparably higher saturated fatty acids [14,15]. IMF content or marbling is a main determinant of meat eating quality in most carcass grading systems [16]. As the IMF increases, so does the eating quality [17] because it influences meat palatability and contributes significantly to juiciness, flavour and tenderness $[18,19]$. Consumers therefore prefer meat with low FMP, moderate IMF and fatty acid composition with proportionately more of the health-promoting omega-3 long-chain polyunsaturated fatty acids (n-3 LC-PUFA). Given that humans and other vertebrates lack the capacity to synthesize n-3 LC-PUFA because they lack the enzyme $\Delta^{15}$ desaturase, they must obtain these from dietary intake sources in order to meet their daily requirement of $500 \mathrm{mg}$ of $\mathrm{n}-3$ LC-PUFA [20]. Lamb producers can tap into the omega-3 functional meat market niche by matching their sheep breeding and production system to meet this health-conscious consumer preference.

Ryegrass is a popular grass species in pasture-based grazing production systems in Australia and New Zealand. Ryegrass contains many phenolic compounds such as gallic and salicylic acids (phenolic acids), tannins, coumarins, flavonoids, $\alpha$-tocopherol, lignans, xanthones and anthocyanidins [21,22]. These phenolic compounds in ryegrass serve as natural antioxidants, anti-inflammatory and anti-septic agents [23] that enhance meat oxidative stability and quality attributes such as nutritive value, flavour and colour. Luciano et al. [24,25] reported that antioxidants in dietary tannins from fresh herbage improved colour stability in Comisana lambs by halting myoglobin oxidation in the muscle and reducing meat colour deterioration. In lambs grazing ryegrass, phenolics and antioxidant enzyme activities have been demonstrated to impact oxidative stability in the Longissimus thoracis et lumborum muscle [26], liver and plasma [27]. Research investigations of perceived sheepmeat eating quality sensory scores [28] and demographic influences [29] on Australian, American and Chinese consumers demonstrated a consistent consumer response to production factors of muscle type, sire, age, and sex. Evidence in the published literature [30] indicates that meat eating quality and fatty acid (FA) composition of lipids in tandem with variable fat deposition at the attainment of maturity, vary in the muscles of sheep due to differences in breed [31-34], physiological status, breeding systems [35], grass-fed versus concentrate feeding [36,37], and sex [38,39].

Linebreeding is a sheep breeding practice of mating closely related animals that can be traced back to one common ancestor with highly desirable attributes. The Tattykeel Australian White (TAW) sheep are renowned for producing the remarkably unique high-eating-quality MARGRA lamb brand, and were developed from more than a decade of rigorous selection, culling and linebreeding of Texel, Van Rooy, Dorper and Poll Dorset with an extensive utilisation of natural mating, artificial 
insemination and embryo transfer. Linebreeding increases the frequency of desirable alleles, selection intensity and homozygosity, hence a tight culling regime and close monitoring of the inbreeding coefficient are key breeding management practices that ensure uniformity and consistency in TAW lamb eating quality. A comprehensive review of omega-3 long-chain polyunsaturated fatty acids (n-3 LC-PUFA) metabolism and meat eating quality in TAW lambs [30] previously identified knowledge gaps in using Longissimus dorsi muscle biopsy sampling of ram and ewe lambs to directly determine the impact of linebreeding and gender on n-3 LC-PUFA, IMF and FMP contents while the animals are young and alive for early selection and breeding purposes. It also recommended the need for further research to better understand the genetic and nutritional interactions between dietary n-3 LC-PUFA oil supplements versus pasture grazing, finishing performance, carcass traits and the unique eating quality of TAW lambs to afford industry players the opportunity to consistently meet consumer preferences as well as key demand and supply determinants of profitability. This paper aims to fill some of these knowledge gaps by assessing the impact of linebreeding and gender on pasture-fed lamb eating quality consistency in antioxidant status, IMF, FMP, n-3 LC-PUFA and to test the hypothesis that variation in healthy lamb eating quality will be a function of lamb gender and not its antioxidant status or inbreeding coefficient (IC) as an index of linebreeding.

\section{Materials and Methods}

\subsection{Animal Ethics}

The use of animals and all procedures performed in this study were approved by the James Cook University Animal Ethics Committee (Permit No. A0015657) in compliance with the Australian Code for Care and Use of Animals for Scientific Purposes (Eighth edition, 2013).

\subsection{Animals and Experimental Design}

The animals used in this study comprised a cohort of 100 ewe and 47 ram lambs at the Tattykeel Australian White stud farm in Black Springs, Oberon, New South Wales, Australia, grazing the same ryegrass pastures in separate paddocks. They were all 10-month-old lambs, with an average liveweight of $36.8 \pm 0.3 \mathrm{~kg}$ (range of 36-38 kg for rams), $37.4 \pm 0.4 \mathrm{~kg}$ (range of $37-38 \mathrm{~kg}$ for ewes), and an overall mean body condition score of $2.5 \pm 0.01$. Carcass performance and meat quality characteristics of TAW had been published [30]. An a priori power analysis was conducted using G-Power to justify an appropriate sample and effect size. As depicted in Figure 1, to achieve a statistical power of $95 \%$ with a critical F-value of 2.5, a minimum total sample size of 146 lambs was sufficient for a large effect size, and a two-sided significance level of 0.05 . Therefore, the cohort of 100 ewe and 47 ram lambs at the Tattykeel Australian White stud farm in Black Springs, Oberon, New South Wales, Australia grazing the same ryegrass pastures in separate paddocks used in this study, was a sufficient and statistically robust experimental design. Total digestible nutrients [40] and metabolisable energy [41] were computed from the nutritive composition of the ryegrass (Table 1) analysed by the Association of Official Analytical Chemists (AOAC) wet chemistry procedure.

Table 1. Nutrient and phenolic antioxidant compositions of ryegrass pastures grazed by Tattykeel Australian White lambs ${ }^{1}$.

\begin{tabular}{|c|c|}
\hline Nutrient & Composition (\% DM) \\
\hline DM & 20.7 \\
\hline $\mathrm{CP}$ & 19.0 \\
\hline ADF & 26.5 \\
\hline NDF & 30.9 \\
\hline EE & 1.8 \\
\hline Ash & 6.8 \\
\hline$\% \mathrm{TDN}$ & 62.5 \\
\hline DE (Mcal/kg) & 2.8 \\
\hline ME (MJ/kg) & 9.4 \\
\hline
\end{tabular}


Table 1. Cont.

\begin{tabular}{lc}
\hline \multicolumn{1}{c}{ Nutrient } & Composition (\% DM) \\
\hline Phenolic Antioxidants: & \\
\hline FCTP (mg GAE/g) & 1.631 \\
FRAP (mmol Fe & \\
\hline
\end{tabular}

\begin{abstract}
${ }^{1}$ DM: dry matter; NDF: neutral detergent fibre; ADF: acid detergent fibre; EE: ether extract; CP: crude protein; $\%$ TDN [40]: total digestible nutrients, calculated as $(\%$ of DM) $=82.38-(0.7515 \times$ ADF [\% of DM] $)$. ME [41]: metabolizable energy, calculated by converting \%TDN to digestible energy $(\mathrm{DE}[\mathrm{Mcal} / \mathrm{kg}]=\% \mathrm{TDN} \times 0.01 \times 4.4)$ which was converted as $\mathrm{ME}=(\mathrm{DE}(\mathrm{Mcal} / \mathrm{kg}) \times 0.82) \times 4.185$; FCTP: Folin-Ciocalteu total phenolics; GAE: gallic acid equivalents; FRAP: ferric reducing antioxidant power.
\end{abstract}

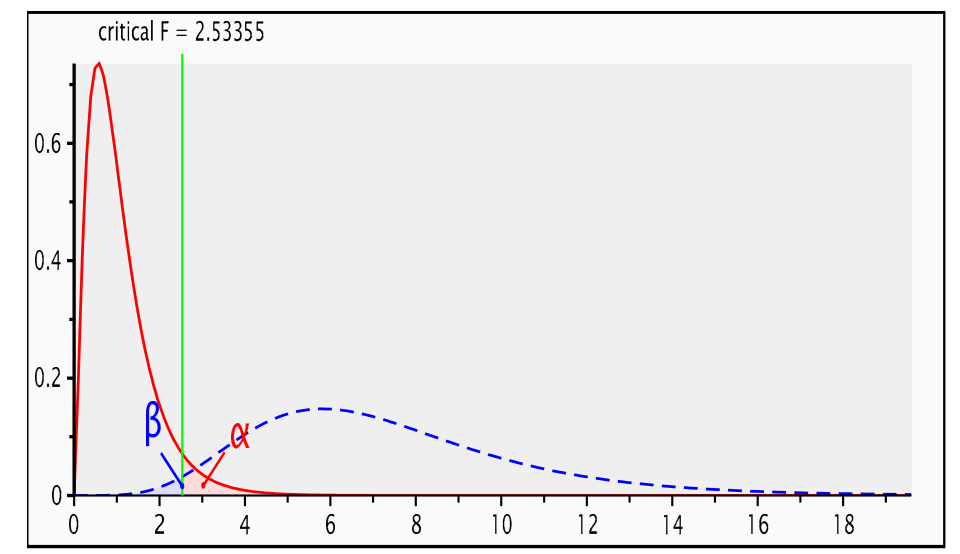

Figure 1. G-Power analysis for statistical power, effect and sample size.

\title{
2.3. Muscle Biopsy Sampling Procedure
}

Longissimus dorsi muscle biopsy samples were taken from the 12th-13th rib interface following the procedure described by Malau-Aduli et al. [42] and are shown in Figure 2. Briefly, the animal was directed into a weighing chute with collapsible sides and some head restraint. The Longissimus dorsi muscle area on the back of the animal between the 12th and 13th ribs was shaved with a small electric clipper and cleaned with $90 \%$ ethanol and chlorhexidine. About $15 \mathrm{~mL}$ of a local anaesthetic agent, lignocaine was administered intramuscularly. Five minutes following the administration of the anaesthetic, a 5-7 cm incision was made with a scalpel blade and about $5 \mathrm{~g}$ of the underlying fat and Longissimus dorsi muscle was sampled. The wound was closed via 3-4 interrupted sutures using surgilon thread. An anti-bacterial aerosol, Cetrigen, was applied to the sutured area on the skin to promote wound healing, prevent flies and the animal was released back to the paddock. No post-operative complications were reported as healing was rapid. The sutures were removed after 10-14 days. The muscle biopsy sample was immediately placed in a plastic bag on dry ice, flushed with nitrogen gas and transferred into a mobile refrigerator. Samples were transported frozen and stored at $-20{ }^{\circ} \mathrm{C}$ pending further analysis in the laboratory. The muscle biopsies were analysed for IMF content, FMP and FA composition. 


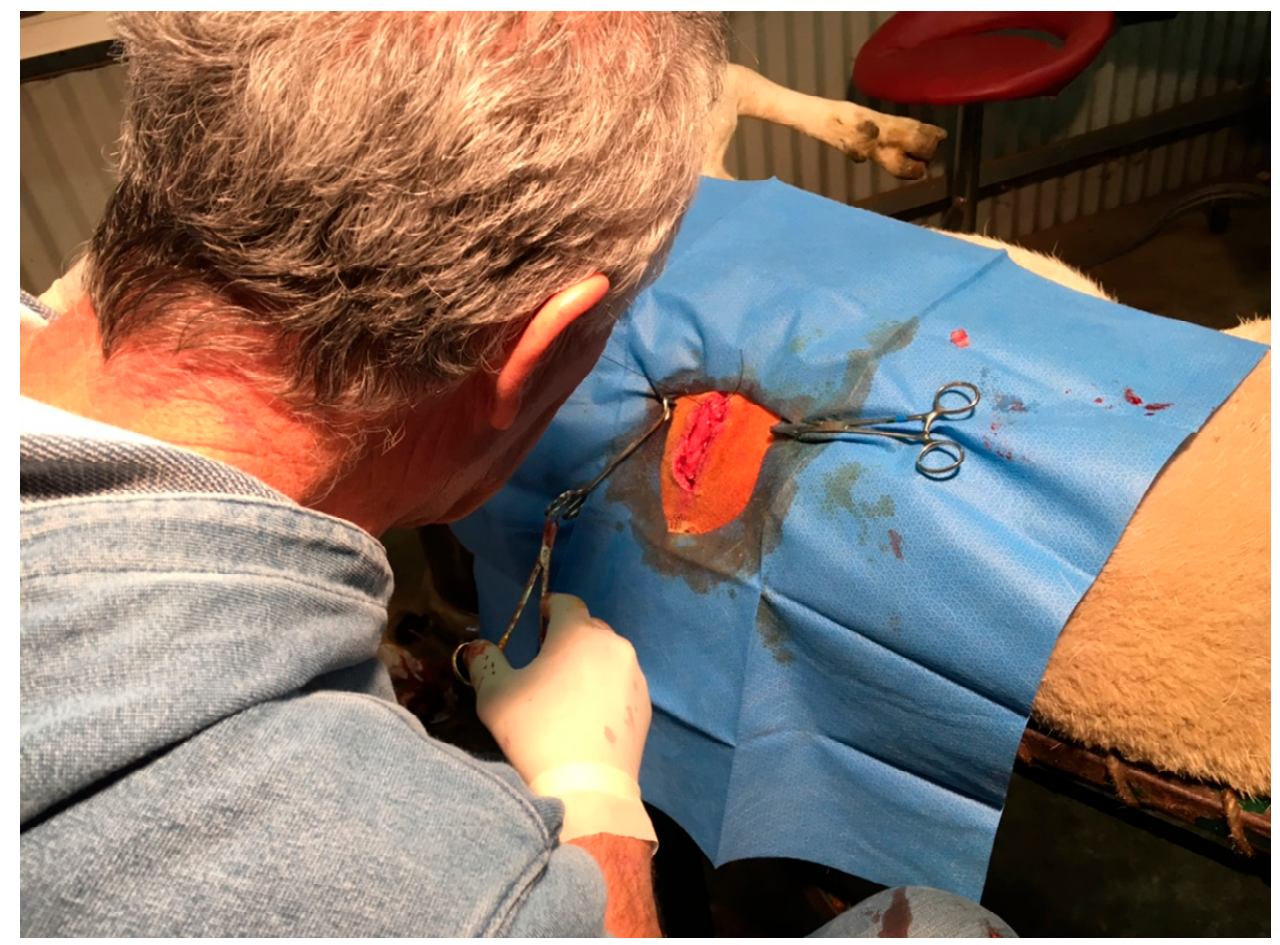

Figure 2. Muscle biopsy sampling technique in Tattykeel Australian White sheep.

\subsection{Determination of Intramuscular Fat}

The procedures of Holman et al. [43] and Flakemore et al. [44] were utilised for IMF determination. Briefly, the muscle sample was homogenised and $1 \mathrm{~g}$ transferred to a labelled $50 \mathrm{~mL}$ plastic tube containing $20 \mathrm{~mL}$ of chloroform: methanol (2:1) solvent and shaken vigorously for $5 \mathrm{~min}$. A filter paper was used to collect the filtrate in another labelled $50 \mathrm{~mL}$ tube. Approximately $5 \mathrm{~mL}$ of $10 \% \mathrm{KCl}$ was added to the filtrate to precipitate and separate the inorganic and lipid fractions into two distinct layers. The upper inorganic layer was removed and discarded, while the lower lipid layer was transferred into a clean, dry, pre-weighed and labelled ceramic crucible and evaporated in a laminar fume hood over a heating block. The crucible was cooled and further dried in a desiccator for 10-20 min before it was re-weighed. Samples were analysed in duplicates to allow for replication and reproducibility. Intramuscular fat percentage was calculated as:

[(Final crucible weight) $-($ Initial crucible weight)/(Initial sample weight $)] \times 100$.

\subsection{Determination of Fat Melting Point}

The procedures of Holman et al. [43] and Flakemore et al. [44] were utilised for FMP determination. Briefly, the crucible containing the extracted IMF was placed in an oven at $100{ }^{\circ} \mathrm{C}$ for about $1-2 \mathrm{~min}$ to melt the fat. Using air suction, the melted fat was sucked into a thin capillary tube and placed in a refrigerator for about $10 \mathrm{~min}$ for the fat to solidify. The fat level in the capillary tube was marked with an indelible pen. The capillary tube was attached to a thermometer and vertically suspended in a beaker containing $80 \mathrm{~mL}$ of cold water, gradually heated over a heating block and closely observed until the fat melted and "slipped" (rose above the mark) within the capillary tube. The temperature at which this slip occurred was recorded as the fat melting point. Samples were analysed in duplicates to allow for replication and reproducibility. TAW lamb has a very low fat melting point and can be liquid at room temperature of $25-28^{\circ} \mathrm{C}$ as shown in Figure 3. 


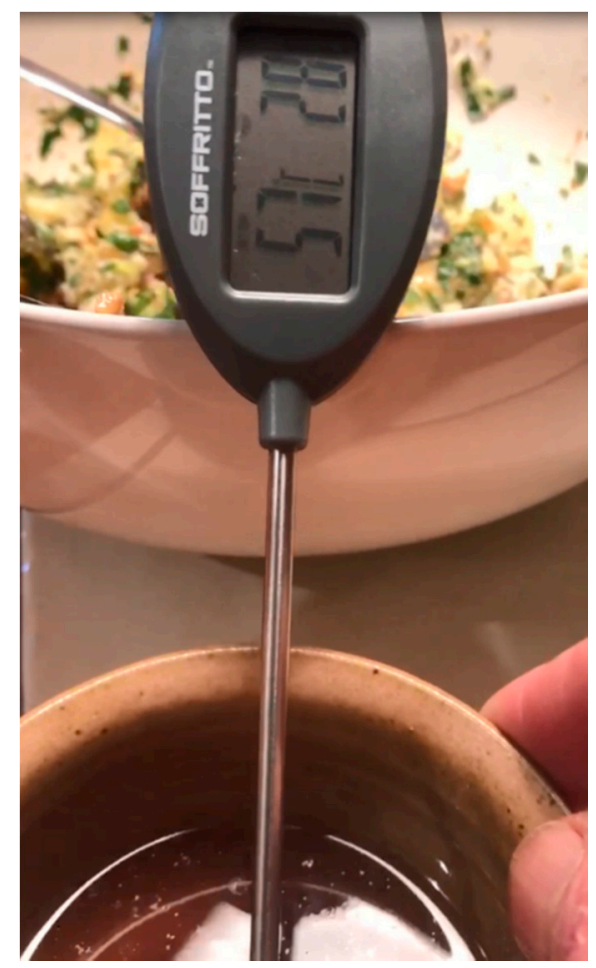

Figure 3. Tattykeel Australian White intramuscular fat (liquid at room temperature) indicating a low fat melting point (FMP).

\subsection{Determination of Fatty Acid Composition}

Fatty acid composition including n-3 LC-PUFA analysis of Longissimus dorsi muscle biopsy samples was analysed by means of gas chromatography-mass spectrophotometry procedure described by Malau-Aduli et al. [45]. Briefly, total lipids in $1 \mathrm{~g}$ of un-homogenised muscle tissue samples were extracted overnight using a modified Bligh and Dyer [46] method. The first step was a single-phase overnight extraction using $\mathrm{CHCl}_{3}: \mathrm{MeOH}_{2} \mathrm{H}_{2} \mathrm{O}(1: 2: 0.8 \mathrm{v} / \mathrm{v})$. The second step involved phase separation with the addition of $\mathrm{CHCl}_{3}$ :saline Milli-Q $\mathrm{H}_{2} \mathrm{O}(1: 1 \mathrm{v} / \mathrm{v})$ followed by rotary evaporation of the lower chloroform phase at $40^{\circ} \mathrm{C}$ to obtain total lipids. The extracted total lipids were separated into lipid classes by thin layer chromatography (TLC) using $100 \mathrm{~mL}$ of the lipid extract reconstituted in hexane [42]. The extract was spotted onto silica gel G plates $\left(200 \times 200 \times 0.25 \mathrm{~mm}^{3}\right)$ with a micropipette. The TLC plate was developed in an acetone/petroleum ether (1:3 vol/vol) solvent system in a tank containing a few crystals of butylated hydroxytoluene (BHT) to prevent oxidation. Triacylglycerols, cholesterol and free fatty acids migrated, while phospholipids remained at the origin of the plate. The areas corresponding to the phospholipids were scraped off the plate and each lipid class transferred to clean screw-capped test tubes for transmethylation and eventual computation of the lipid conversion factor (LCF) of 0.912 on the basis of $g$ fatty acids/g total lipids ( 0.083 phospholipids, 0.829 triacylglycerols and $0 \%$ cholesterol because cholesterol does not contain any fatty acids). An aliquot from each total lipid extract was used for transmethylation with $\mathrm{MeOH}: \mathrm{CHCl}_{3}: \mathrm{HCl}(10: 1: 1 v / v)$ for $2 \mathrm{~h}$ at $80^{\circ} \mathrm{C}$. Fatty acid methyl esters (FAME) were extracted three times using hexane: $\mathrm{CHCl}_{3}(4: 1 v / v)$. A known concentration of an internal standard (19:0) was added in a $1500 \mu \mathrm{L}$ vial containing the extracted FAME. The FAME were analysed on a 7890B gas chromatograph (Agilent Technologies, Palo Alto, CA, USA) equipped with an Equity ${ }^{\mathrm{TM}}-1$ fused $15 \mathrm{~m}$ silica capillary column with $0.1 \mathrm{~mm}$ internal diameter and $0.1 \mu \mathrm{m}$ film thickness (Supelco, Bellefonte, PA, USA), a flame ionisation detector, a split/splitless injector and an Agilent Technologies 7683 B Series autosampler. The gas chromatograph conditions were: splitless mode injection; carrier gas He; initial oven temperature $120^{\circ} \mathrm{C}$ and then increased to $270{ }^{\circ} \mathrm{C}$ at flow rates of $10{ }^{\circ} \mathrm{C} / \mathrm{min}$ and to $310^{\circ} \mathrm{C}$ at $5{ }^{\circ} \mathrm{C} / \mathrm{min}$. The Agilent Technologies ChemStation software (Palo 
Alto, CA, USA) was used to quantify fatty acid peaks. The fatty acid identities were confirmed by gas chromatograph-mass spectrometric (GC/MS) analysis using a Finnigan Thermoquest $\mathrm{GCQ}^{\mathrm{TM}}$ GC/MS fitted with an on-column injector and Thermoquest Xcalibur software (Austin, TX, USA). The gas chromatograph (GC) was equipped with an HP-5 cross-linked methyl silicone-fused silica capillary column ( $50 \mathrm{~m} \times 0.32 \mathrm{~mm}$ internal diameter) which is of similar polarity to the column described above. The carrier gas was helium (head pressure $30 \mathrm{kPa}$ ) and GC conditions had been previously described by Miller et al. [47]. Fatty acid percentages were computed as follows: FA $\%=$ [(individual fatty acid area) $*(100)] /$ (sum total area of fatty acids). Fatty acid contents were calculated as follows: FA mg/100 g $=($ Total lipid $) *($ LCF $[0.912]) *([\% \mathrm{FA}] / 100) * 1000$, where 0.912 was the derived lipid conversion factor similar to the one cited by Clayton [48].

\subsection{Extraction and Purification of Phenolic Compounds}

Solid-phase extraction, purification and analysis of phenolics in the ryegrass utilised the procedure described in detail by López-Andrés et al. [27]. Briefly, $2.5 \mathrm{~g}$ of the ryegrass was chopped to pass through a $1 \mathrm{~mm}$ sieve and homogenised at 4000 r.p.m. in $15 \mathrm{~mL}$ of acetone/water 70/30 v/v for $1 \mathrm{~min}$ and sonicated for $6 \mathrm{~min}$ in a water bath. Homogenates were centrifuged at $4{ }^{\circ} \mathrm{C}$ for $15 \mathrm{~min}$ at $3000 \times \mathrm{g}$ and the supernatants filtered with Whatman filter papers. About $10 \mathrm{~mL}$ of the filtered supernatant was acidified with $0.5 \mathrm{M} \mathrm{H}_{2} \mathrm{SO}_{4}$ and loaded onto reversed phase cartridges (C18 Sep-Pak Vac WAT043395, WATERS, Milan, Italy) preconditioned with methanol and distilled water to disrupt polyphenol-binding protein. The extracted phenolics were eluted with $2 \mathrm{~mL}$ methanol and stored in a $-30{ }^{\circ} \mathrm{C}$ freezer until ready for Folin-Ciocalteu (FCTP) and ferric reducing antioxidant power (FRAP) assays using a double-beam spectrophotometer (model UV-1601, Shimadzu Corporation, Milan, Italy) to measure the absorbance of the samples at $725 \mathrm{~nm}$ and $593 \mathrm{~nm}$, respectively. Details of both assay procedures have been described [27] and will not be repeated herein.

\subsection{Antioxidant Enzyme Activities}

Antioxidant activities of glutathione peroxidase, catalase and superoxide dismutase enzymes in the muscle were assayed as described by Petron et al. [26]. Briefly, about $5 \mathrm{~g}$ of the Longissimus dorsi muscle was homogenised in $25 \mathrm{~mL}$ of $0.005 \mathrm{M}$ phosphate buffer ( $\mathrm{pH}$ 7.0) and centrifuged at $4{ }^{\circ} \mathrm{C}$ for $20 \mathrm{~min}$ at $7000 \mathrm{~g}$. The supernatant fraction was filtered through glass wool and used to determine glutathione peroxidase, catalase and superoxide dismutase enzyme activities. By measuring the inhibition of pyrogallol autoxidation, total superoxide dismutase (SOD) activity ( $\mathrm{Cu}-\mathrm{Zn} \mathrm{SOD}+\mathrm{Mn}$ SOD) was determined where one unit was taken as the activity that inhibits the reaction by $50 \%$ [1]. To determine glutathione peroxidase enzyme activity, the oxidation of NADPH at $22{ }^{\circ} \mathrm{C}$ was used. The assay medium ( $3 \mathrm{~mL}$ ) consisted of $1 \mathrm{mM}$ reduced glutathione, $0.15 \mathrm{mM} \mathrm{NADPH}, 0.15 \mathrm{mM} \mathrm{H}_{2} \mathrm{O}_{2}, 40 \mathrm{mM}$ potassium phosphate buffer (pH 7.0), $0.5 \mathrm{mM}$ EDTA, $1 \mathrm{mM} \mathrm{NaN}_{3}, 1.5$ units of glutathione reductase, and $300 \mu \mathrm{L}$ of the muscle extract. Absorbance at $340 \mathrm{~nm}$ was recorded over $3 \mathrm{~min}$. An extinction coefficient of $6300 \mathrm{M}^{-1} \mathrm{~cm}^{-1}$ was used for calculation of NADPH concentration. One unit of glutathione peroxidase enzyme activity was defined as the amount of extract required to oxidize $1 \mu \mathrm{mol}$ of NADPH per min at $22^{\circ} \mathrm{C}$ [1]. Catalase enzyme activity was performed as described by Petron et al. [1]. About $2 \mathrm{~mL}$ of the Longissimus dorsi muscle supernatant $(2 \mathrm{~mL})$ was reacted at room temperature $\left(\sim 22^{\circ} \mathrm{C}\right)$ with $1 \mathrm{~mL}$ of $30 \mathrm{mM} \mathrm{H}_{2} \mathrm{O}_{2}$ in $0.05 \mathrm{M}$ phosphate buffer ( $\left.\mathrm{pH} 7.0\right)$, and the reaction $\left(\mathrm{H}_{2} \mathrm{O}_{2}\right.$ decomposition) was monitored by measuring the absorbance at $240 \mathrm{~nm}$ during the initial $30 \mathrm{~s}$. An extinction coefficient of $0.040 \mathrm{~cm}^{2} \mu \mathrm{mol}^{-1}$ was used for calculation of $\mathrm{H}_{2} \mathrm{O}_{2}$ splitting. One unit (U) of catalase activity was defined as the amount of extract needed to decompose $1 \mu \mathrm{mol}$ of $\mathrm{H}_{2} \mathrm{O}_{2}$ per min [26].

\subsection{Statistical Analysis}

IC as an index of linebreeding, estimates the probability that two alleles in an individual lamb will be homozygous ( $\mathrm{HH}$ or hh) rather than heterozygous $(\mathrm{Hh})$ because the parents are related and have one common ancestor. In other words, IC measures the extent to which two genes at any locus in 
an individual lamb are identical by descent from the common ancestor(s) of the two parents. IC was computed as:

$$
\mathrm{F}_{\mathrm{X}}=\Sigma\left[(1 / 2)^{\mathrm{n}+1}\left(1+\mathrm{F}_{\mathrm{A}}\right)\right]
$$

where $\mathrm{F}_{\mathrm{X}}=\mathrm{IC}$ of lamb $\mathrm{X}, \Sigma$ = summation, $\mathrm{n}=$ number of common ancestors connecting the parents of lamb X and $F_{A}$ is the IC of the common ancestor $\mathrm{A}$.

Fatty acids, IMF, FMP, antioxidants and enzyme activities were analysed as dependent variables using multivariate analysis of variance (MANOVA) after fitting the fixed effects of gender and IC in General Linear Model procedures (PROC GLM) using Statistical Analysis System software (SAS) version 9.4 (SAS Institute, Cary, NC, USA) [49]. First-order interactions between gender and IC were initially tested but later dropped from the final model due to non-significance. The initial full statistical model used for the analysis was:

$$
Y=\mu+G_{i}+B_{j}+(G B)_{i j}+e_{i j k}
$$

where $\mathrm{Y}=$ dependent variable (FMP, IMF, FA, antioxidants and enzyme activities), $\mu$ = overall mean, $\mathrm{G}_{\mathrm{i}}=$ Gender, $\mathrm{B}_{\mathrm{j}}=$ Inbreeding Coefficient,$(\mathrm{GB})_{\mathrm{ij}}=$ first-order interaction between gender and inbreeding coefficient, and $\mathrm{e}_{\mathrm{ijk}}=$ residual error. Level of significance threshold was set at $p<0.05$ and differences between least square means were established using Tukey's pairwise comparison test.

\section{Results}

\subsection{Nutrient Composition of the Grazed Ryegrass Pasture, Muscle Phenolics and Antioxidant Enzyme Activities}

The ewe and ram lambs utilised in this study grazed high-quality ryegrass whose nutrient composition and antioxidant status is presented in Table 1 and fatty acid profile in Table 2. The low dry matter is indicative of fresh pasture with high moisture content, while the high phenolic antioxidants, crude protein, low neutral detergent and high metabolisable energy are all indicative of high palatability, digestibility and total digestible nutrients from the ryegrass pastures that are typical during spring. There were no significant differences due to gender (Table 3) and inbreeding coefficient (Table 4) in total phenolics and antioxidant enzyme activities of glutathione peroxidase, catalase and superoxide dismutase in the Longissimus dorsi muscle of these ryegrass pasture-fed lambs.

Table 2. Fatty acid composition of grazed ryegrass pasture.

\begin{tabular}{cc}
\hline Fatty Acid & \% Total Fatty Acids \\
\hline $14: 0$ & 0.6 \\
$15: 0$ & 0.2 \\
$16: 1 \mathrm{n}-9 \mathrm{c}$ & 0.0 \\
$16: 1 \mathrm{n}-7 \mathrm{c}$ & 0.2 \\
$16: 0$ & 15.7 \\
17:0 & 0.5 \\
18:2n-6 LA & 14.8 \\
18:3n-3 ALA & 57.6 \\
18:1n-9c & 1.0 \\
18:1n-7c & 0.2 \\
18:1n-7t & 0.0 \\
18:0 & 0.1 \\
$20: 4 n-6$ ARA & 0.0 \\
$20: 5 n-3$ EPA & 0.0 \\
$20: 3 n-6$ & 0.1 \\
20:4n-3 & 0.1 \\
20:2n-6 & 0.1 \\
20:0 & 1.6 \\
$22: 5 n-6$ DPA-6 & 0.0 \\
\hline
\end{tabular}


Table 2. Cont.

\begin{tabular}{cc}
\hline Fatty Acid & \% Total Fatty Acids \\
\hline $22: 6 n-3$ DHA & 0.0 \\
22:5n-3 DPA-3 & 0.0 \\
$22: 0$ & 1.0 \\
$23: 0$ & 0.3 \\
$24: 0$ & 0.9 \\
$\sum$ SFA & 20.9 \\
$\sum$ MUFA & 4.9 \\
$\sum$ PUFA & 73.1 \\
$\sum$ n-3 LC-PUFA & 0.1 \\
$\sum$ n-3 PUFA & 58.0 \\
$\sum$ n-6 PUFA & 15.2 \\
$\sum$ other FA & 1.0 \\
n-6/n-3 & 0.3
\end{tabular}

LA, linoleic acid; ALA, $\alpha$-linolenic acid; EPA, eicosapentaenoic acid; DHA, docosahexaenoic acid; DPA, docosapentaenoic acid; ARA, arachidonic acid; $\Sigma$ SFA, total saturated fatty acids; $\Sigma$ MUFA, total monounsaturated fatty acids; and total polyunsaturated fatty acids ( $\mathrm{PPUFA}$ ). $\sum$ SFA is the sum of 14:0, 15:0, 16:0, 17:0, 18:0, 20:0, 21:0, 22:0, 23:0, 24:0; $\sum$ MUFA is the sum of 14:1, 16:1n-13t, 16:1n-9, 16:1n-7, 16:1n-7t, 16:1n-5c, 17:1n-8+a17:0, 18:1n-9, 18:1n-7t, 18:1n-5, 18:1n-7, 18:1a, 18:1b, 18:1c, 19:1a, 19:1b, 20:1n-11, 20:1n-9, 20:1n-7, 20:1n-5, 22:1n-9, 22:1n-11, 24:1n-9; ¿PUFA is the sum of 18:4n-3, 18:3n-6, 18:2n-6, 18:3n-3, 20:3, 20:4n-3, 20:4n-6, 20:5n-3, 20:3n-6, 20:2n-6, 22:6n-3, 22:5n-3, 22:5n-6, 22:4n-6; $\sum \mathrm{n}-3$ LC-PUFA is the sum of 20:5n-3, 20:4n-3, 22:6n-3, 22:5n-3; $\sum \mathrm{n}-3$ PUFA is the sum of 18:3n-3, 18:4n-3, 20:4n-3, 20:5n-3, 22:6n-3, 22:5n-3; $\sum \mathrm{n}-6$ PUFA is the sum of 18:2n-6, 18:3n-6, 20:4n-6, 20:3n-6, 20:2n-6, $22: 5 n-6,22: 4 n-6$; $\sum$ other FA is the sum of other individual FA present at $<0.1 \%$ except ARA, DHA, EPA, and DPA.

Table 3. Effect of gender (Means \pm s.d.) on fat melting point, intramuscular fat, fatty acids, antioxidant phenolics and enzyme activities in the Longissimus dorsi muscle of ryegrass-fed Tattykeel Australian White (TAW) lambs ${ }^{1}$.

\begin{tabular}{|c|c|c|c|c|}
\hline Variable & $\operatorname{Ram}(n=47)$ & Ewe $(n=100)$ & Overall $(n=147)$ & $P$-Value \\
\hline Fat Melting Point $\left({ }^{\circ} \mathrm{C}\right)$ & $35.5 \pm 1.5$ & $34.2 \pm 2.4$ & $34.6 \pm 2.3$ & 0.0001 \\
\hline Intramuscular fat (\%) & $3.4 \pm 0.3$ & $4.4 \pm 1.4$ & $4.1 \pm 1.3$ & 0.0001 \\
\hline FCTP (mg GAE/g) & $1.142 \pm 0.0036$ & $1.171 \pm 0.0042$ & $1.156 \pm 0.0039$ & 0.4723 \\
\hline 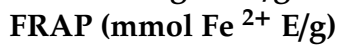 & $5.481 \pm 0.0172$ & $5.605 \pm 0.0198$ & $5.543 \pm 0.0185$ & 0.2982 \\
\hline GSH-Px (U/g) & $0.085 \pm 0.0012$ & $0.091 \pm 0.0024$ & $0.088 \pm 0.0018$ & 0.0921 \\
\hline Cat $(\mathrm{U} / \mathrm{g})$ & $39.8 \pm 1.3$ & $40.1 \pm 1.5$ & $40.0 \pm 1.4$ & 0.0882 \\
\hline SOD (U/g) & $63.8 \pm 5.7$ & $64.9 \pm 6.1$ & $64.4 \pm 5.9$ & 0.1566 \\
\hline \multicolumn{5}{|c|}{ Fatty Acids (mg /100 g) } \\
\hline C12:0 & $0.1 \pm 0.5$ & $0.0 \pm 0.0$ & $0.0 \pm 0.3$ & 0.1453 \\
\hline C13:0 & $3.2 \pm 5.4$ & $0.8 \pm 3.2$ & $1.5 \pm 4.2$ & 0.0009 \\
\hline C14:0 & $438.7 \pm 492.2$ & $153.8 \pm 291.9$ & $244.9 \pm 389.7$ & 0.0001 \\
\hline C14:1 & $11.9 \pm 15.7$ & $3.0 \pm 5.8$ & $5.8 \pm 10.9$ & 0.0001 \\
\hline C15:0 & $168.6 \pm 172.2$ & $46.1 \pm 98.0$ & $85.3 \pm 138.3$ & 0.0001 \\
\hline C16:0 & $3321.2 \pm 2631.5$ & $1093.0 \pm 1457.6$ & $1805.4 \pm 2170.2$ & 0.0001 \\
\hline C16:1 & $260.7 \pm 237.0$ & $94.6 \pm 134.1$ & $147.7 \pm 189.5$ & 0.0001 \\
\hline $\mathrm{C} 17: 0$ & $321.0 \pm 307.3$ & $109.1 \pm 237.7$ & $176.8 \pm 279.1$ & 0.0001 \\
\hline C17:1 & $233.0 \pm 247.8$ & $75.3 \pm 137.5$ & $125.7 \pm 194.0$ & 0.0001 \\
\hline C18.0 & $2692.0 \pm 2283.4$ & $1016.9 \pm 1649.3$ & $1552.5 \pm 2025.2$ & 0.0001 \\
\hline C18:1 & $4942.6 \pm 4041.0$ & $1920.3 \pm 2489.0$ & $2886.6 \pm 3368.4$ & 0.0001 \\
\hline C18:2 n-6 LA & $423.5 \pm 266.6$ & $125.4 \pm 80.0$ & $220.7 \pm 214.9$ & 0.0001 \\
\hline C18:3 n-3 ALA & $262.6 \pm 209.0$ & $72.5 \pm 81.6$ & $133.3 \pm 161.9$ & 0.0001 \\
\hline C18:3 n-6 & $2.1 \pm 4.3$ & $2.4 \pm 6.5$ & $2.3 \pm 5.9$ & 0.8014 \\
\hline C18:4 n-3 & $3.7 \pm 8.6$ & $1.6 \pm 10.1$ & $2.3 \pm 9.7$ & 0.2262 \\
\hline CLA & $117.9 \pm 129.7$ & $63.7 \pm 190.0$ & $81.1 \pm 174.4$ & 0.0788 \\
\hline C19:1 & $39.1 \pm 41.4$ & $14.3 \pm 26.3$ & $22.2 \pm 33.8$ & 0.0001 \\
\hline C20:0 & $20.3 \pm 18.4$ & $7.3 \pm 10.8$ & $11.4 \pm 15.0$ & 0.0001 \\
\hline C20:1 & $26.3 \pm 28.4$ & $8.1 \pm 12.2$ & $13.9 \pm 20.7$ & 0.0001 \\
\hline$C 20: 2$ n-6 & $7.9 \pm 8.9$ & $2.1 \pm 3.1$ & $4.0 \pm 6.2$ & 0.0001 \\
\hline
\end{tabular}


Table 3. Cont.

\begin{tabular}{|c|c|c|c|c|}
\hline Variable & $\operatorname{Ram}(n=47)$ & Ewe $(n=100)$ & Overall $(n=147)$ & $P$-Value \\
\hline C20:3 & $8.4 \pm 4.1$ & $11.7 \pm 12.7$ & $10.6 \pm 10.8$ & 0.0839 \\
\hline C20:3 n-6 & $8.8 \pm 4.9$ & $6.1 \pm 2.1$ & $7.0 \pm 3.5$ & 0.0001 \\
\hline C20:4 n-3 & $4.8 \pm 7.3$ & $2.1 \pm 1.5$ & $3.0 \pm 4.5$ & 0.0005 \\
\hline C20:4 n-6 & $36.4 \pm 14.2$ & $33.7 \pm 8.0$ & $34.6 \pm 10.4$ & 0.1473 \\
\hline C20:5 n-3 (EPA) & $26.0 \pm 8.5$ & $24.3 \pm 5.2$ & $24.9 \pm 6.5$ & 0.1402 \\
\hline $\mathrm{C} 21: 0$ & $2.0 \pm 2.5$ & $0.6 \pm 1.4$ & $1.0 \pm 1.9$ & 0.0001 \\
\hline C22:0 & $2.8 \pm 3.3$ & $2.3 \pm 1.3$ & $2.5 \pm 2.2$ & 0.1342 \\
\hline C22:1 & $0.4 \pm 1.2$ & $0.8 \pm 1.6$ & $0.7 \pm 1.5$ & 0.1613 \\
\hline C22:4 n-6 & $0.6 \pm 1.2$ & $1.4 \pm 0.5$ & $1.2 \pm 0.9$ & 0.0001 \\
\hline C22:5 n-3 (DPA) & $22.5 \pm 11.6$ & $25.2 \pm 8.0$ & $24.4 \pm 9.4$ & 0.097 \\
\hline C22:5 n-6 & $0.0 \pm 0.1$ & $0.2 \pm 0.2$ & $0.1 \pm 0.2$ & 0.0001 \\
\hline C22:6 n-3(DHA) & $5.8 \pm 3.7$ & $8.3 \pm 2.7$ & $7.5 \pm 3.2$ & 0.0001 \\
\hline C23:0 & $2.5 \pm 2.3$ & $2.5 \pm 0.7$ & $2.5 \pm 1.4$ & 0.7207 \\
\hline C24:0 & $2.2 \pm 2.0$ & $2.8 \pm 0.9$ & $2.6 \pm 1.4$ & 0.008 \\
\hline $\mathrm{C} 24: 1 \mathrm{n}-9 \mathrm{c}$ & $1.7 \pm 2.1$ & $3.9 \pm 1.8$ & $3.2 \pm 2.1$ & 0.0001 \\
\hline EPA+DHA & $31.9 \pm 11.3$ & $32.6 \pm 7.0$ & $32.4 \pm 8.5$ & 0.6265 \\
\hline $\mathrm{EPA}+\mathrm{DHA}+\mathrm{DPA}$ & $54.4 \pm 21.8$ & $57.9 \pm 13.6$ & $56.7 \pm 16.7$ & 0.2388 \\
\hline SFA & $6971.2 \pm 5684.7$ & $2434.4 \pm 3700.9$ & $3884.9 \pm 4896.6$ & 0.0001 \\
\hline MUFA & $2120.3 \pm 2772.9$ & $5515.7 \pm 4577.1$ & $3205.9 \pm 3786.7$ & 0.0001 \\
\hline PUFA & $380.7 \pm 331.9$ & $931.1 \pm 614.7$ & $556.7 \pm 510.0$ & 0.0001 \\
\hline PUFA/SFA & $0.2 \pm 0.1$ & $0.2 \pm 0.1$ & $0.2 \pm 0.1$ & 0.0036 \\
\hline$\sum$ n-3 PUFA & $134.1 \pm 96.5$ & $325.5 \pm 231.7$ & $195.3 \pm 176.7$ & 0.0001 \\
\hline $\bar{\sum}$ n-6 PUFA & $479.3 \pm 279.5$ & $171.3 \pm 85.2$ & $269.8 \pm 224.3$ & 0.0001 \\
\hline n-6/ n-3 PUFA & $1.6 \pm 0.5$ & $1.4 \pm 0.3$ & $1.5 \pm 0.4$ & 0.0001 \\
\hline
\end{tabular}

1 FCTP: Folin-Ciocalteu Total Phenolics; GAE: Gallic acid equivalents; FRAP: Ferric reducing antioxidant power. Antioxidant enzyme activities of GSH-Px: glutathione peroxidase, Cat: catalase (Cat) and SOD: superoxide dismutase. $\sum$ SFA sum of saturated FAs: C12:0+C13:0+C14:0CC14:0+C15:0+C15:0+C15:0+C16:0+ $\mathrm{C} 17: 0+\mathrm{C} 18: 0+\mathrm{C} 20: 0+\mathrm{C} 21: 0+\mathrm{C} 22: 0+\mathrm{C} 23: 0+\mathrm{C} 24: 0 ; \quad \sum$ MUFA sum of monounsaturated FAs: $\mathrm{C} 14: 1+\mathrm{C} 16: 1+\mathrm{C} 17: 1+$ $\mathrm{C} 18: 1+\mathrm{C} 19: 1+\mathrm{C} 20: 1+\mathrm{C} 21: 1+\mathrm{C} 22: 1+\mathrm{C} 24: 1$. $\sum$ PUFA is the sum of polyunsaturated FA: $\mathrm{C} 18: 2 \mathrm{n}-6+\mathrm{C} 18: 3 \mathrm{n}-3+\mathrm{C} 18: 3 \mathrm{n}-6+$ C18:4 n-3+CLA+C20:2 n-6+C20:3+C20:3 n-6+C20:4 n-3+C22:4 n-6+C20:5 n-3+C22:5n-3+C22:5 n-6+C22:6 n-3. $\sum n-6$ PUFA is the sum of $n-6$ PUFA: C18:2 n- $6+C 18: 3 n-6+C 20: 2 n-6+C 20: 4 n-6+C 20: 3 n-6+C 20: 4 n-6+C 22: 5 n-6$. $n n-3$ PUFA is the sum of n-3 PUFA: C18:3 n-3+C18:4n-3+C20:4 n-3+C20:5 n-3+C22:5n-3+C22:6n-3.

Table 4. Effect of inbreeding coefficients (Means \pm s.d.) on fat melting point, intramuscular fat, fatty acids, antioxidant phenolics and enzyme activities in the Longissimus dorsi muscle of ryegrass-fed TAW lambs ${ }^{1}$.

\begin{tabular}{ccccc}
\hline & \multicolumn{4}{c}{ Inbreeding Coefficient (\%) } \\
\hline Variable & $\begin{array}{c}\text { Low } \mathbf{( 0 - 5 )} \\
(\boldsymbol{n}=\mathbf{4 9 )}\end{array}$ & $\begin{array}{c}\text { Medium(6-10) } \\
(\boldsymbol{n}=\mathbf{4 9 )}\end{array}$ & $\begin{array}{c}\text { High (Above 10) } \\
(\boldsymbol{n}=\mathbf{4 9 )}\end{array}$ & $\boldsymbol{P}$-Value \\
\hline Fat Melting Points $\left.\mathbf{(}^{\circ} \mathbf{C}\right)$ & $34.9 \pm 2.1$ & $34.2 \pm 2.4$ & $34.8 \pm 2.8$ & 0.225 \\
Intramuscular fat & $4.1 \pm 1.4$ & $4.0 \pm 1.2$ & $4.1 \pm 1.0$ & 0.9148 \\
FCTP (mg GAE/g) & $1.271 \pm 0.0014$ & $1.269 \pm 0.0019$ & $1.290 \pm 0.0014$ & 0.8524 \\
FRAP (mmol Fe ${ }^{++}$E/g) & $6.018 \pm 0.0027$ & $6.083 \pm 0.0045$ & $6.102 \pm 0.0086$ & 0.2352 \\
GSH-Px (U/g) & $0.091 \pm 0.0041$ & $0.086 \pm 0.0036$ & $0.089 \pm 0.0062$ & 0.0896 \\
Cat (U/g) & $40.5 \pm 1.8$ & $40.1 \pm 1.6$ & $40.7 \pm 1.9$ & 0.1843 \\
SOD (U/g) & $64.8 \pm 5.7$ & $65.0 \pm 5.9$ & $64.5 \pm 5.3$ & 0.0972 \\
\hline & Fatty Acids $\mathbf{( m g / 1 0 0 ~ g )}$ & & \\
\hline C12:0 & $0.0 \pm 0.4$ & $0.0 \pm 0.0$ & $0.0 \pm 0.0$ & 0.6757 \\
C13:0 & $2.3 \pm 4.6$ & $0.7 \pm 3.5$ & $0.0 \pm 0.0$ & 0.0574 \\
C14:0 & $340.3 \pm 479.9$ & $127.5 \pm 176.7$ & $94.6 \pm 50.8$ & 0.0033 \\
C14:1 & $7.7 \pm 11.9$ & $3.6 \pm 9.4$ & $2.4 \pm 1.7$ & 0.0609 \\
C15:0 & $116.6 \pm 152.0$ & $47.7 \pm 112.7$ & $27.1 \pm 22.9$ & 0.0074 \\
C16:0 & $2377.1 \pm 2509.5$ & $1100.6 \pm 1410.2$ & $923.7 \pm 527.9$ & 0.0013 \\
C16:1 & $194.1 \pm 215.9$ & $90.9 \pm 135.4$ & $71.8 \pm 38.3$ & 0.0033 \\
C17:0 & $241.4 \pm 322.4$ & $98.9 \pm 193.4$ & $61.0 \pm 32.9$ & 0.006 \\
\hline
\end{tabular}


Table 4. Cont.

\begin{tabular}{|c|c|c|c|c|}
\hline \multirow[b]{2}{*}{ Variable } & \multicolumn{4}{|c|}{ Inbreeding Coefficient (\%) } \\
\hline & $\begin{array}{l}\text { Low }(0-5) \\
(n=49)\end{array}$ & $\begin{array}{l}\text { Medium(6-10) } \\
\quad(n=49)\end{array}$ & $\begin{array}{l}\text { High (Above 10) } \\
\qquad(n=49)\end{array}$ & $P$-Value \\
\hline C17:1 & $165.6 \pm 202.9$ & $78.3 \pm 178.8$ & $46.6 \pm 26.2$ & 0.0174 \\
\hline C18.0 & $2130.6 \pm 2447.3$ & $840.2 \pm 938.8$ & $655.2 \pm 288.8$ & 0.0004 \\
\hline C18:1 & $3704.7 \pm 3831.0$ & $1885.3 \pm 2423.3$ & $1552.9 \pm 690.9$ & 0.0036 \\
\hline C18:2 n-6 (LA) & $271.1 \pm 244.2$ & $158.9 \pm 156.5$ & $139.0 \pm 65.3$ & 0.0053 \\
\hline C18:3 n-3 (ALA) & $170.3 \pm 179.0$ & $89.0 \pm 129.2$ & $63.7 \pm 33.0$ & 0.0067 \\
\hline C18:3 n-6 & $3.1 \pm 7.8$ & $1.3 \pm 0.9$ & $1.5 \pm 0.8$ & 0.032 \\
\hline C18:4 n-3 & $3.1 \pm 11.5$ & $1.4 \pm 7.0$ & $0.4 \pm 0.3$ & 0.5311 \\
\hline CLA & $114.4 \pm 219.4$ & $40.4 \pm 75.8$ & $24.9 \pm 13.7$ & 0.032 \\
\hline C19:1 & $29.4 \pm 37.4$ & $13.6 \pm 27.5$ & $9.1 \pm 5.2$ & 0.0139 \\
\hline C20:0 & $15.5 \pm 17.7$ & $6.5 \pm 8.4$ & $5.2 \pm 2.7$ & 0.001 \\
\hline C20:1 & $18.4 \pm 22.3$ & $8.7 \pm 17.9$ & $5.2 \pm 2.2$ & 0.0124 \\
\hline$C 20: 2$ n-6 & $5.3 \pm 7.2$ & $2.2 \pm 4.3$ & $2.0 \pm 2.1$ & 0.0092 \\
\hline C20:3 & $11.0 \pm 14.3$ & $10.2 \pm 2.7$ & $9.4 \pm 2.7$ & 0.8782 \\
\hline$C 20: 3 n-6$ & $7.6 \pm 3.9$ & $6.2 \pm 2.7$ & $5.6 \pm 1.1$ & 0.8782 \\
\hline C20:4 n-3 & $3.6 \pm 5.3$ & $2.3 \pm 3.1$ & $1.6 \pm 0.6$ & 0.171 \\
\hline C20:4 n-6 & $32.8 \pm 11.6$ & $36.6 \pm 8.4$ & $38.0 \pm 8.3$ & 0.0737 \\
\hline C20:5 n-3 (EPA) & $24.3 \pm 7.0$ & $25.8 \pm 5.9$ & $23.0 \pm 4.8$ & 0.3091 \\
\hline C21:0 & $1.6 \pm 2.3$ & $0.4 \pm 0.9$ & $0.1 \pm 0.2$ & 0.0009 \\
\hline C22:0 & $3.0 \pm 2.7$ & $1.8 \pm 1.1$ & $1.6 \pm 0.8$ & 0.0055 \\
\hline C22:1 & $0.8 \pm 1.9$ & $0.6 \pm 0.9$ & $0.3 \pm 0.3$ & 0.5598 \\
\hline C22:4 n-6 & $1.2 \pm 1.0$ & $1.2 \pm 0.7$ & $1.3 \pm 0.7$ & 0.9005 \\
\hline C22:5 n-3 (DPA) & $24.7 \pm 11.5$ & $23.9 \pm 5.7$ & $23.3 \pm 5.0$ & 0.8515 \\
\hline C22:5 n-6 & $0.1 \pm 0.2$ & $0.2 \pm 0.2$ & $0.2 \pm 0.3$ & 0.3705 \\
\hline C22:6 n-3(DHA) & $7.4 \pm 3.8$ & $7.6 \pm 2.4$ & $7.5 \pm 3.1$ & 0.9816 \\
\hline $\mathrm{C} 23: 0$ & $2.7 \pm 1.7$ & $2.7 \pm 1.0$ & $2.0 \pm 1.1$ & 0.2737 \\
\hline C24:0 & $2.7 \pm 1.5$ & $2.5 \pm 1.2$ & $2.3 \pm 1.3$ & 0.674 \\
\hline $\mathrm{C} 24: 1 \mathrm{n}-9 \mathrm{c}$ & $2.9 \pm 2.1$ & $3.5 \pm 2.1$ & $3.7 \pm 2.1$ & 0.2498 \\
\hline $\mathrm{EPA}+\mathrm{DHA}$ & $31.8 \pm 9.5$ & $33.4 \pm 7.1$ & $30.6 \pm 7.6$ & 0.4708 \\
\hline $\mathrm{EPA}+\mathrm{DHA}+\mathrm{DPA}$ & $56.5 \pm 19.8$ & $57.3 \pm 11.9$ & $53.8 \pm 12.4$ & 0.8738 \\
\hline SFA & $5231.3 \pm 5786.8$ & $2228.5 \pm 2775.3$ & $1772.7 \pm 913.9$ & 0.0007 \\
\hline MUFA & $4123.6 \pm 4281.0$ & $2084.4 \pm 2782.6$ & $1691.9 \pm 761.3$ & 0.0036 \\
\hline PUFA & $680.1 \pm 577.2$ & $407.1 \pm 373.2$ & $341.5 \pm 105.3$ & 0.0037 \\
\hline PUFA/SFA & $0.2 \pm 0.1$ & $0.2 \pm 0.1$ & $0.2 \pm 0.0$ & 0.0781 \\
\hline$\sum n-3$ PUFA & $233.4 \pm 196.1$ & $149.9 \pm 141.9$ & $119.6 \pm 27.5$ & 0.0114 \\
\hline$\sum$ n-6 PUFA & $321.2 \pm 255.7$ & $206.6 \pm 162.3$ & $187.6 \pm 71.6$ & 0.0067 \\
\hline n-6/ n-3 PUFA & $1.5 \pm 0.4$ & $1.5 \pm 0.3$ & $1.5 \pm 0.3$ & 0.8487 \\
\hline
\end{tabular}

\subsection{Intramuscular Fat Content (IMF)}

IMF ranged from $3.4 \%$ to $8.2 \%$, but ewe lambs had significantly higher IMF ( $4.4 \pm 1.4 \%)$ than ram lambs $(3.4 \pm 0.3 \%)$ as shown in Figure $4 \mathrm{~A}$. Irrespective of gender, the overall IMF was $4.1 \pm 1.3 \%$ (Table 3). As shown in Table 4, IC as an index of linebreeding was classified into low (0-5\%), medium $(6-10 \%)$ and high $(>10 \%)$ and ranged from $0 \%$ to $15.6 \%$. As IC increased, there were no differences in IMF (Table 4 and Figure 4B). 
A

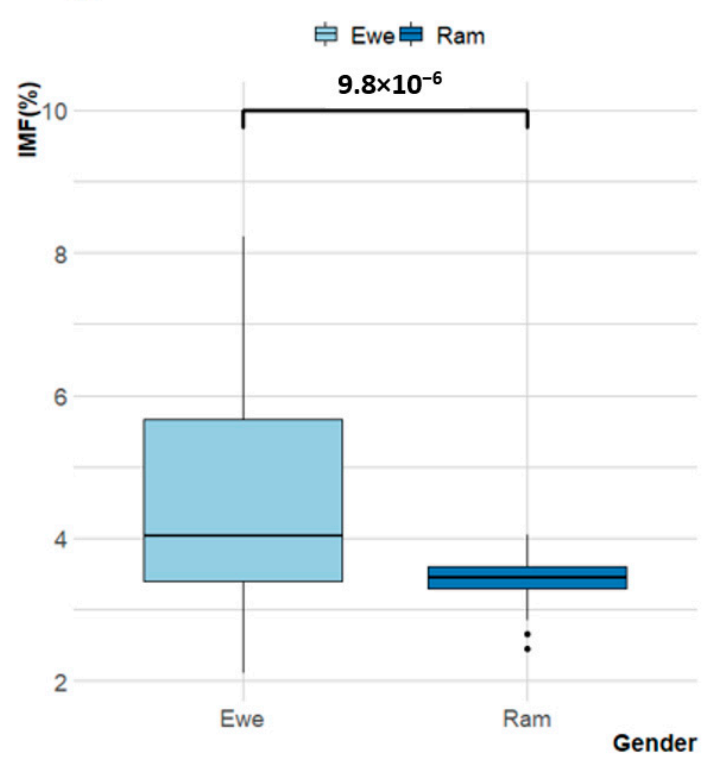

B

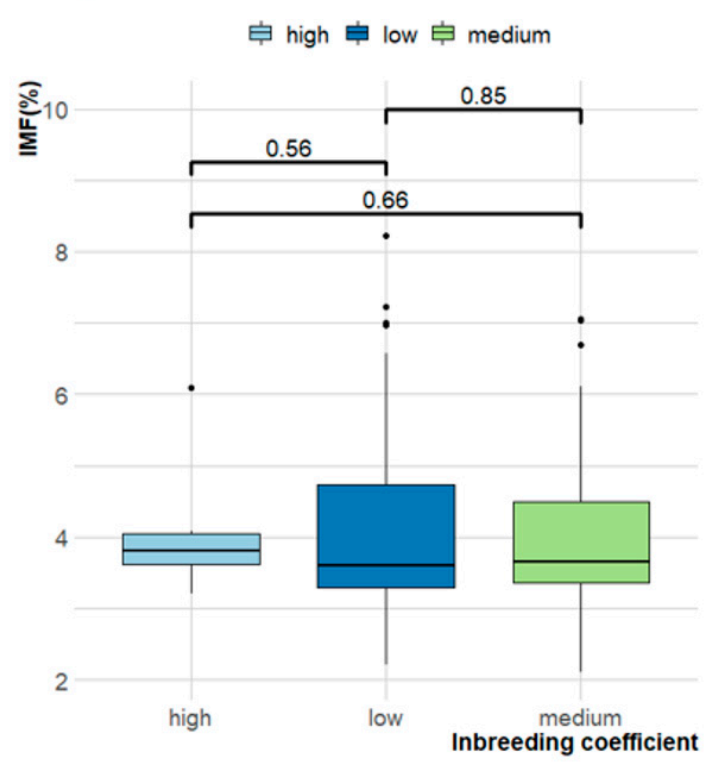

Figure 4. Variation in intramuscular fat (IMF) percentage of Tattykeel Australian White (TAW): (A) gender; (B) Inbreeding Coefficient (IC).

\subsection{Fat Melting Point (FMP)}

FMP ranged from 28 to $39^{\circ} \mathrm{C}$, but ewe lambs had significantly lower FMP $\left(34.26 \pm 2.43{ }^{\circ} \mathrm{C}\right)$ than ram lambs $\left(35.5 \pm 1.5^{\circ} \mathrm{C}\right)$ as shown in Figure 5. Irrespective of gender, the overall FMP was $34.6 \pm 2.3^{\circ} \mathrm{C}$ (Table 3). Similar to IMF, IC was not significantly associated with FMP (Table 4 and Figure $4 \mathrm{~B})$.

A

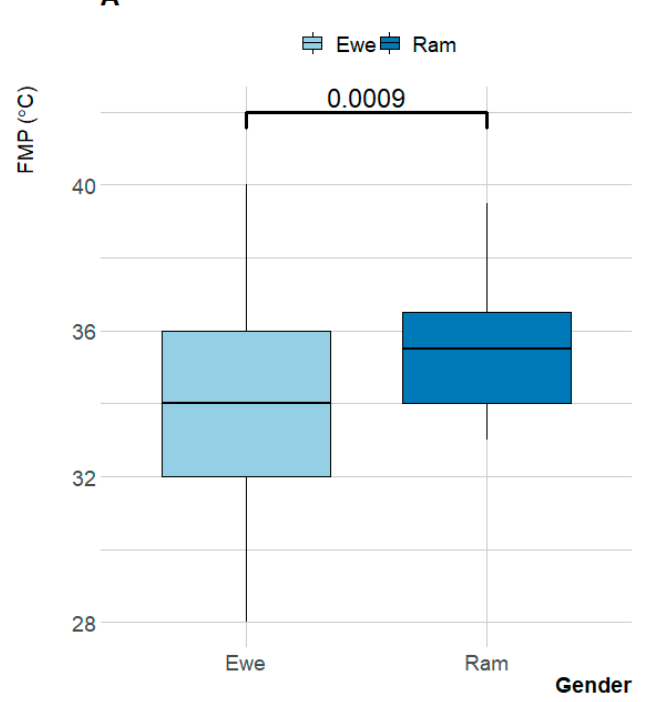

B

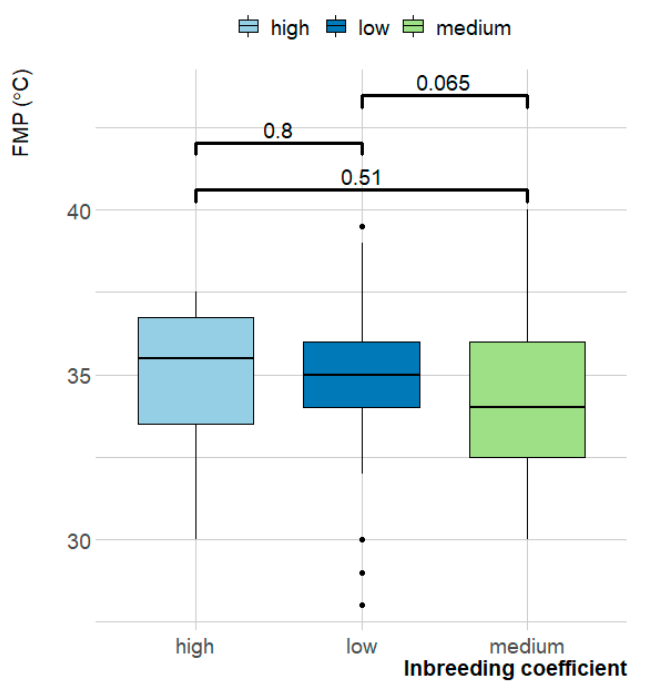

Figure 5. Variation in fat melting point (FMP) percentage of Tattykeel Australian White (TAW): (A) gender; (B) Inbreeding Coefficient (IC).

\subsection{Faty Acid Composition}

The fatty acid composition in ewe and ram lambs in $\mathrm{mg} / 100 \mathrm{~g}$ tissue is shown in Table 3. It shows that ewe lambs had significantly $(P<0.0001)$ higher C22:5n-3 (DPA), C22:6n-3 (DHA), C18:3n-6, C20:3, C22:4n-6, C22:5n-6, MUFA, PUFA and $\Sigma \mathrm{n}-3$ and lower SFA fatty acids than ram lambs. Although n-3 LC-PUFA ranged from "source" to "good source" levels of 33-69 mg/100 g in individual lambs, overall, 
there were no gender differences in the health-promoting EPA, DPA, EPA+DHA and EPA+DHA+DPA (Table 3). As IC increased, there were no differences in C20:5n-3 (EPA), DHA, DPA, EPA+DHA, $\mathrm{EPA}+\mathrm{DHA}+\mathrm{DPA}$ and $\sum \mathrm{n}-6 / \sum \mathrm{n}-3$ ratio, while increases in C18:3n-3 (ALA), MUFA, PUFA, C18:1, C18:2n-6, C18:3N-6, $\sum$ n-3 PUFA and $\sum$ n-6 PUFA were observed as IC decreased from high to low (Table 4).

\section{Discussion}

Consumer preferences, behaviours, perceptions and satisfaction with the eating quality of meat products are intricately linked to flavour, odour, colour, aroma, taste and juiciness [50,51]. Previous studies [52-57] identified diet-related "pastoral flavour" in lamb, also described as "milky", "barnyard", "sheepy" or "faecal" flavour, to negatively impact consumer liking. It is thought that this unpleasant "pastoral flavour" originates from skatole (3-methylindole) and indole derivatives from the degradation of tryptophan, 4-methylphenol and other branched chain fatty acids in the rumen [58]. Lamb has also been reported to have a distinct age-related "mutton flavour" and aroma associated with the three branched chain fatty acids 4-methylnonanoic, 4-methyloctanoic and 4-ethyloctanoic acids [59]. Other previous studies had demonstrated that the nutritional background of pasture-fed ruminants confers a higher muscle $\alpha$-tocopherol antioxidant status compared to those on concentrate based diets [60-64]. Several internal and external factors influence the quantity and quality of lipids in animal products due to genetics-nutrition interactions in the expression of genes controlling fat metabolism [65] and these include the key attributes of fat melting point, intramuscular fat and fatty acid composition. The Folin-Ciocalteu total phenolics, ferric reducing antioxidant power and antioxidant enzyme activities of glutathione peroxidase, catalase and superoxide dismutase values in the present study were consistent with those reported in the Longissimus thoracis et lumborum muscle [26], liver and plasma [27] of lambs grazing ryegrass. However, in our present study, the observation that none of the dietary phenolic compounds and antioxidant enzyme activities detected in the Longissimus dorsi muscle were affected by the lamb gender (Table 3) or inbreeding coefficient (Table 4) suggests that gender and linebreeding had no direct impact on the antioxidant status and deposition mechanism in the muscle tissue of MARGRA lambs. This implies that TAW sheep grazing ryegrass rich in phenolics contributed to an improved overall meat oxidative stability with similar deposition and bioavailability in ewe and ram lambs irrespective of inbreeding coefficient.

\subsection{FMP}

The FMP range of $28-39^{\circ} \mathrm{C}$ and an overall mean of $34.6 \pm 2.3^{\circ} \mathrm{C}$ obtained for TAW in the present study is well below the range of $40.6-48.0^{\circ} \mathrm{C}$ and $41.5-44.0^{\circ} \mathrm{C}$ reported by Flakemore et al. [13] and Holman et al. [43] in purebred and crossbred Merino, Dorset, Black and White Suffolk sheep. The presence of double or triple bonds in the FA structure leads to lower melting points because the higher the proportions of MUFA and PUFA, the more easily such bonds can be broken and the lower the fat melting points compared to the more stable SFA with high FMP. Smith et al. [66] reported that these SFA contributed to an elevation in the hardness of fat in beef, while Flakemore et al. [13] reported that the softness or hardness of fat has safety implications for meat processors and boning room personnel in abattoirs. From our results in the present study (Table 3), the lesser the SFA concentration and more MUFA and PUFA implied a low FMP, indicating that TAW is not only a healthier meat product for consumers, but also a safe product to meat processors in the abattoir due to ease of processing. It was also apparent that elevated proportions of SFA, especially palmitic (C16:0) and stearic (C18:0) acids in ram lambs, could have been the reason for the higher FMP than in ewe lambs. While the underpinning reasons behind the observed sex differences in FMP are not definitive from our present study, we can speculate that hormonal differences between ram and ewe lambs could have possibly had an indirect influence on FMP through IMF. This is because it has been reported that in intact bovine males, testosterone binds to receptors within the muscle and increases amino acid incorporation into protein, thus increasing muscular development, growth rate and muscle mass 
without simultaneous increases in IMF $[67,68]$. The lesser the IMF, the higher the FMP, and the higher the IMF as seen in TAW ewe lambs, the lower the FMP. This would seem to explain why, in the current study, the ewe lambs had higher IMF and lower FMP than ram lambs. Further research on the likely underlying molecular mechanisms behind FMP and IMF variation through lipogenic genes controlling fat metabolism like fatty acid binding protein-4, fatty acid synthase and stearoyl-CoA desaturase currently being investigated with TAW lambs in our laboratory, would assist in shedding more light.

\subsection{IMF}

IMF influences meat palatability and contributes to its juiciness, flavour and tenderness with direct linkage between intramuscular fat deposition and gender, age, genetics and nutrition [67-69]. The overall mean IMF of $4.4 \pm 0.2 \%$ in the current study surpasses the suggested minimum Australian threshold of $4 \%$ for lamb palatability by Pannier et al. [70] who reported an overall average IMF of $4.23 \pm 0.01 \%$ in lambs from sires selected for leanness. The IMF values in TAW pasture-fed lambs in the current study are much higher than the $1.25 \pm 0.22 \%$ in lot-fed Manchega lambs reported by Gomez-Cortes et al. [71] in contrast to the expectation that lambs sacrificed after 42 days in the feedlot should have higher IMF. This would most likely be a combination of both genetic and nutritional effects with TAW having a genetic predisposition for a comparatively higher and faster rate of IMF deposition in response to ryegrass pasture feeding than other breeds such as the Manchega lambs fed concentrate rations with high fibrous components. Published reports of gender differences in IMF are not unanimous in their findings. For instance, while Pannier et al. [70] and McPhee et al. [16,72] reported significant sex differences in IMF just as we also observed in TAW lambs, Okeudo and Moss [73] did not find any differences in intramuscular lipid and fatty acid profiles of sheep comprising four sex-types. In beef cattle, Cafferky et al. [67] stated that the higher IMF values in steers than intact bulls are attributed to the diminished physiological effects of androgen, which reduces plasma lipids, increases lipolysis by adipocytes and stimulates androgen receptors to directly upregulate the lipogenic gene expression of fatty acid synthase and acetyl-CoA carboxylase $[74,75]$ while simultaneously downregulating the lipolytic gene expression of monoglyceride lipase and adipose triglyceride lipase [55]. Hence, castration contributes to improved IMF deposition through increased lipogenesis and lipid uptake while decreasing lipolysis [76]. Given the hormonal differences between ewe and ram lambs, similar genetic, physiological and biochemical pathways may be involved, and our lab is currently exploring the sequencing and expression of fatty acid binding protein-4, fatty acid synthase and stearoyl-CoA desaturase genes in TAW to unravel and better understand the underpinning mechanisms of fat metabolism.

It was quite interesting that IC had no impact on FMP and IMF (Table 3). This is very significant from an eating quality perspective because it indicates that TAW lambs can produce consistently high-quality MARGRA meat product with low FMP and high IMF regardless of linebreeding with IC in the $0-15.6 \%$ range. To our current knowledge, the present study is the first of its kind to provide a significant insight into the impact of IC on meat eating quality in lamb as the only other reported research on inbreeding was in milking cows where Carrara et al. [77] reported significant $(P<0.04)$ impact of inbreeding on milk PUFA.

\subsection{Omega-3 Long-Chain Polyunsaturated Fatty Acids}

The ingestion of n-3 LC-PUFA confers a number of health benefits, including inhibiting cardiovascular diseases, cancer, and diabetes, obesity and neurodegenerative diseases such as amyotrophic lateral sclerosis, Parkinson's, and Alzheimer's [78] as well as improve visual and brain development [79]. Le et al. [80] reported that Food Standards of Australia and New Zealand (FSANZ) guidelines stipulate that for any food or meat to be termed a 'source' of n-3 LC PUFA, its EPA and DHA levels must be greater than $30 \mathrm{mg}$ per $100 \mathrm{~g}$ per serve. TAW lambs had $32.4 \pm 8.5 \mathrm{mg}$ per $100 \mathrm{~g}$ of muscle, thus surpassing the $30 \mathrm{mg}$ limit set by FSANZ for 'source' claim. The main FA in pastures is ALA, a precursor of the more potent n-3 LC-PUFA [81], especially EPA, DHA and DPA, which 
have important roles to play in human health. The observations that, as IC increased, there were no differences in FMP, IMF, C20:5n-3 (EPA), DHA, DPA, EPA+DHA, EPA+DHA+DPA and $\Sigma$ n- $6 / \Sigma$ n-3 ratio and that increases in C18:3n-3 (ALA), MUFA, PUFA, C18:1, C18:2n-6 and C18:3n-6 were observed as IC decreased, indicate that linebreeding in the $0-15.6 \%$ range is not in any way detrimental to consistency in health-promoting n-3 LC-PUFA in TAW lambs. Such observations represent the first piece of experimental evidence regarding the impact of IC on omega-3 FA. Our data herein provide scientific evidence that TAW MARGRA lamb contains higher levels of health beneficial n-3 LC-PUFA than in other Australian lamb breeds previously reported by Ponnampalam et al. [82-86], Flakemore et al. [87], Knight et al. [88,89], De Brito et al. [90] and Fowler et al. [91]. Sex has been shown to influence heart and muscle FA composition, although the differences were restricted to only a few FA [45]. Previous studies have attributed FA variations due to sex as arising from sex-linked hormonal differences, which affect development and rumen biohydrogenation [45].

\section{Conclusions}

The results obtained from this study provide the first detailed scientific evidence of TAW MARGRA lamb with low SFA, high IMF, MUFA, n-3 LC-PUFA and lower FMP. Therefore, the meat from TAW lambs provides anecdotal and scientific evidence for adequate meat oxidative stability and human health benefits associated with n-3 LC-PUFA to consumers. This study clearly provides a scientific confirmation of the unique meat eating quality traits of TAW lambs. Based on nutritional value to consumers, this study reinforces the health benefits derived from consuming TAW MAGRA lamb in view of its high EPA, DHA and DPA contents. This high n-3 LC-PUFA profile of TAW MARGRA lamb has put this breed well ahead of others in terms of healthy meat products. Our findings clearly show significant gender variation between ram and ewe lambs. The lower SFA and higher MUFA and PUFA contents make MARGRA lamb fats very soft and smooth melting in the mouth without sticking to the palate due to its low FMP and healthier composition. This study provides evidence that IC is inconsequential in affecting antioxidant status, IMF, FMP and n-3 LC-PUFA in linebred and pasture-fed TAW sheep. This is because the observed variation in individual fatty acids was mainly driven by gender differences between ewes and rams, hence the need to accept the tested hypothesis. The practical implication is that health-conscious meat consumers are reassured by the scientific evidence herein of the consistency in the eating quality of MARGRA lamb brand from TAW sheep regardless of its linebred origin.

Author Contributions: Conceptualization, A.E.O.M.-A.; methodology, A.E.O.M.-A., J.R.O., S.B.P., software, A.E.O.M.-A.; validation, A.E.O.M.-A., S.B.P., J.R.O., formal analysis, S.B.P; O.A.A.; investigation, S.B.P.; resources, A.E.O.M.-A., R.T.K. and O.A.A.; data curation, writing — original draft preparation, S.B.P.; writing-reviewing and editing, A.E.O.M.-A., R.T.K. and O.A.A.; supervision, A.E.O.M.-A., R.T.K. and O.A.A.; project administration, A.E.O.M.-A.; funding acquisition, A.E.O.M.-A. All authors have read and agreed to the published version of the manuscript.

Funding: This research was funded by the Innovation Connections Research Grant from the Australian Commonwealth Government's Dept of Industry, Innovation, Climate Change, Science, Research and Tertiary Education, Tattykeel Australian White Pty Ltd. and a PhD scholarship funded by the James Cook University Postgraduate Research Scholarship (JCUPRS), Queensland, Australia, awarded to the first named author.

Acknowledgments: The authors gratefully acknowledge JCUPRS, James Cook University College of Public Health, Medical and Veterinary Sciences (PhD scholarship), the Australian Commonwealth Dept of Industry, Innovation, Climate Change, Science, Research and Tertiary Education (research funding), Tattykeel Australian White Pty Ltd. (access to flock, farm resources, research funding), Commonwealth Scientific and Industrial Research Organisation Marine and Atmosphere Hobart (fatty acid analysis) and the National Veterinary Research Institute Vom, Nigeria (study leave approval for the first-named author).

Conflicts of Interest: The authors declare no conflict of interest. The funders had no role in the design of the study; collection, analyses, or interpretation of data; in the writing of the manuscript, or in the decision to publish the results. 


\section{References}

1. FAO. FAO. Food and Agriculture Organization of the United Nations. Meat Quality 2014. Available online: http://www.fao.org/ag/againfo/themes/en/meat/quality_meat (accessed on 3 November 2020).

2. MLA. MLA. Meat and Livestock Australia. Eating Quality 2020. Available online: https://www.mla.com.au/ research-and-development/feeding-finishing-nutrition/eating-quality (accessed on 3 November 2020).

3. Ripoll, G.; Joy, M.; Panea, B. Consumer perception of the quality of lamb and lamb confit. Foods 2018, 7, 80. [CrossRef] [PubMed]

4. Elmasry, G.; Barbin, D.F.; Sun, D.-W.; Allen, P. Meat quality evaluation by hyperspectral imaging technique: An overview. Crit. Rev. Food Sci. Nutr. 2012, 52, 689-711. [CrossRef] [PubMed]

5. Guerrero, A.; Velandia-Valero, M.; Campo, M.M.; Sañudo, C. Some factors that affect ruminant meat quality: From the farm to the fork. Review. Acta Scientiarum. Anim. Sci. 2013, 35, 335-347.

6. Milewski, S. Health-promoting properties of sheep products. Med. Weter. 2006, 62, 516-519.

7. Alves, L.G.C.; Osório, J.D.S.; Fernandes, A.; Ricardo, H.D.A.; Cunha, C. Produção de carne ovina com foco no consumidor. Enciclopédia Biosf. 2014, 10, 2399-2415.

8. Miller, R. Drivers of consumer liking for beef, pork, and lamb: A review. Foods 2020, 9, 428. [CrossRef] [PubMed]

9. Hocquette, J.-F.; Richardson, R.I.; Prache, S.; Medale, F.; Duffy, G.; Scollan, N.D. The future trends for research on quality and safety of animal products. Ital. J. Anim. Sci. 2005, 4, 49-72. [CrossRef]

10. Indurain, G.; Carr, T.; Goñi, M.; Insausti, K.; Beriain, M. The relationship of carcass measurements to carcass composition and intramuscular fat in Spanish beef. Meat Sci. 2009, 82, 155-161. [CrossRef]

11. Hocquette, J.-F.; Minsant, P.; Daudin, J.-D.; Cassar-Malek, I.; Rémond, D.; Doreau, M.; Sans, P.; Bauchart, D.; Verbeke, D.; Picard, B.; et al. Will meat be produced in vitro in the future? INRA Prod. Anim. 2013, 26, 363-374. [CrossRef]

12. Valdez-Arjona, L.P.; Ramírez-Mella, M. Pumpkin waste as livestock feed: Impact on nutrition and animal health and on quality of meat, milk, and egg. Animals 2019, 9, 769. [CrossRef]

13. Flakemore, A.R.; McEvoy, P.D.; Balogun, R.O.; Malau-Aduli, B.S.; Nichols, P.; Malau-Aduli, A.E.O. Degummed crude canola oil supplementation affects fat depot melting points in purebred and first-cross Merino sheep. Anim. Vet. Sci. 2014, 2, 75-80. [CrossRef]

14. Webb, E.C.; O'neill, H. The animal fat paradox and meat quality. Meat Sci. 2008, 80, 28-36. [CrossRef] [PubMed]

15. Wood, J.; Enser, M.; Fisher, A.; Nute, G.; Sheard, P.; Richardson, R.; Hughes, S.; Whittington, F. Fat deposition, fatty acid composition and meat quality: A review. Meat Sci. 2008, 78, 343-358. [CrossRef] [PubMed]

16. McPhee, M.; Hopkins, D.; Pethick, D. Intramuscular fat levels in sheep muscle during growth. Aust. J. Expt. Agric. 2008, 48, 904-909. [CrossRef]

17. Pannier, L.; Gardner, G.; O'Reilly, R.; Pethick, D. Factors affecting lamb eating quality and the potential for their integration into an MSA sheepmeat grading model. Meat Sci. 2018, 144, 43-52. [CrossRef]

18. Pannier, L.; Gardner, G.; Pearce, K.; McDonagh, M.; Ball, A.; Jacob, R.; Pethick, D. Associations of sire estimated breeding values and objective meat quality measurements with sensory scores in Australian lamb. Meat Sci. 2014, 96, 1076-1087. [CrossRef]

19. Thompson, J.M. The effects of marbling on flavour and juiciness scores of cooked beef, after adjusting to a constant tenderness. Aust. J. Expt. Agric. 2004, 44, 645-652. [CrossRef]

20. Nichols, P.D.; Petrie, J.; Singh, S. Long-chain omega-3 oils-an update on sustainable sources. Nutrients 2010, 2, 572-585. [CrossRef]

21. Pańka, D.; Piesik, D.; Jeske, M.; Baturo-Cieśniewska, A. Production of phenolics and the emission of volatile organic compounds by perennial ryegrass (Lolium perenne L.)/Neotyphodium lolii association as a response to infection by Fusarium poae. J. Plant Physiol. 2013, 170, 1010-1019. [CrossRef]

22. Stewart, A.J.; Stewart, R.F. Encyclopedia of Ecology; Sven, E.J., Brian, D.F., Eds.; Elsevier Science: Amsterdam, The Netherlands, 2008; pp. 2682-2689. ISBN 978-0-08-045405-4.

23. Choi, K.C.; Son, Y.O.; Hwang, J.M.; Kim, B.T.; Chae, M.; Lee, J.C. Antioxidant, anti-inflammatory and anti-septic potential of phenolic acids and flavonoid fractions isolated from Lolium multiflorum. Pharm. Biol. 2017, 55, 611-619. [CrossRef] 
24. Luciano, G.; Monahan, F.J.; Vasta, V.; Biondi, L.; Lanza, M.; Priolo, A. Dietary tannins improve lamb meat colour stability. Meat Sci. 2009, 81, 120-125. [CrossRef] [PubMed]

25. Luciano, G.; Monahan, F.J.; Vasta, V.; Biondi, L.; Lanza, M.; Priolo, A. Lipid and colour stability of meat from lambs fed fresh herbage or concentrate. Meat Sci. 2009, 82, 193-199. [CrossRef] [PubMed]

26. Petron, M.J.; Raes, K.; Claeys, E.; Lourenco, M.; Fremaut, D.; De Smet, S. Effect of grazing pastures of different botanical composition on antioxidant enzyme activities and oxidative stability of lamb meat. Meat Sci. 2007, 75, 737-745. [CrossRef] [PubMed]

27. López-Andrés, P.; Luciano, G.; Vasta, V.; Gibson, T.M.; Scerra, M.; Biondi, L.; Priolo, A.; Mueller-Harvey, I. Antioxidant effects of ryegrass phenolics in lamb liver and plasma. Animal 2014, 8, 51-57. [CrossRef]

28. O’Reilly, R.A.; Pannier, L.; Gardner, G.E.; Garmyn, A.J.; Luo, H.; Meng, Q.; Miller, M.F.; Pethick, D.W. Influence of demographic factors on sheepmeat sensory scores of American, Australian and Chinese consumers. Foods 2020, 9, 529. [CrossRef]

29. O’Reilly, R.; Pannier, L.; Gardner, G.; Garmyn, A.; Luo, H.; Meng, Q.; Miller, M.; Pethick, D. Minor differences in perceived sheepmeat eating quality scores of Australian, Chinese and American consumers. Meat Sci. 2020, 164, 108060. [CrossRef]

30. Pewan, S.B.; Otto, J.R.; Huerlimann, R.; Budd, A.M.; Mwangi, F.W.; Edmunds, R.C.; Holman, B.W.B.; Henry, M.L.E.; Kinobe, R.T.; Adegboye, O.A.; et al. Genetics of omega-3 long-chain polyunsaturated fatty acid metabolism and meat eating quality in Tattykeel Australian White lambs. Genes 2020, 11, 587. [CrossRef]

31. Zhang, C.; Zhang, H.; Liu, M.; Zhao, X.; Luo, H. Effect of breed on the volatile compound precursors and odor profile attributes of lamb meat. Foods 2020, 9, 1178. [CrossRef]

32. Souza, D.; Selaive-Villarroel, A.; Pereira, E.; Osório, J.; Teixeira, A. Growth performance, feed efficiency and carcass characteristics of lambs produced from Dorper sheep crossed with Santa Inês or Brazilian Somali sheep. Small Rum. Res. 2013, 114, 51-55. [CrossRef]

33. Monaco, C.A.; Freire, M.T.A.; Melo, L.; Rosa, A.F.; Carrer, C.D.C.; Trindade, M.A. Eating quality of meat from six lamb breed types raised in Brazil. J. Sci. Food Agric. 2015, 95, 1747-1752. [CrossRef]

34. De Vargas-Junior, F.; Martins, C.F.; Feijó, G.L.D.; Teixeira, A.; Leonardo, A.P.; Ricardo, H.D.A.; Fernandes, A.R.M.; Reis, F.A. Evaluation of genotype on fatty acid profile and sensory of meat of indigenous Pantaneiro sheep and Texel or Santa Inês crossbred finished on feedlot. Small Rum. Res. 2019, 173, 17-22. [CrossRef]

35. Monteschio, J.D.O.; Burin, P.C.; Leonardo, A.P.; Fausto, D.A.; Silva, A.L.A.; Ricardo, H.A.; Da Silva, M.C.; De Souza, M.R.; Junior, F.M.D.V. Different physiological stages and breeding systems related to the variability of meat quality of indigenous Pantaneiro sheep. PLoS ONE 2018, 13, e0191668. [CrossRef] [PubMed]

36. Hoffman, L.C.; Claasen, B.; Van der Merwe, D.A.; Cloete, S.W.P.; Cloete, J.J.E. The effects of production system and sex on the sensory quality characteristics of Dorper lamb. Foods 2020, 9, 725. [CrossRef] [PubMed]

37. Nuernberg, K.; Fischer, A.; Nuernberg, G.; Ender, K.; Dannenberger, D. Meat quality and fatty acid composition of lipids in muscle and fatty tissue of Skudde lambs fed grass versus concentrate. Small Rum. Res. 2008, 74, 279-283. [CrossRef]

38. Van der Merwe, D.A.; Brand, T.S.; Hoffman, L.C. Slaughter characteristics of feedlot-finished premium South African lamb: Effects of sex and breed type. Foods 2020, 9, 648. [CrossRef] [PubMed]

39. Vnučec, I.; Držaić, V.; Mioč, B.; Prpić, Z.; Antunović, Z.; Kegalj, A. Effect of sex on meat chemical composition and fatty acid composition in suckling Pag sheep lambs. Veterinarski. Arhiv. 2016, 86, 217-227.

40. Bath, D.L.; Marble, V.L. Testing Alfalfa Hay for Its Feeding Value; Leaflet 21437 WREP 109; Division of Agriculture \& Natural Resources University of California: Oakland, CA, USA, 1989.

41. Robinson, P.H.; Givens, D.I.; Getachew, G. Evaluation of NRC, UC Davis and ADAS approaches to estimate the metabolizable energy values of feeds at maintenance energy intake from equations utilizing chemical assays and in vitro determinations. Anim. Feed Sci. Tech. 2004, 114, 75-90. [CrossRef]

42. Malau-Aduli, A.E.O.; Siebert, B.D.; Bottema, C.D.K.; Pitchford, W.S. Breed comparison of the fatty acid composition of muscle phospholipids in Jersey and Limousin cattle. J. Anim. Sci. 1998, 76, 766-773. [CrossRef]

43. Holman, B.; Flakemore, A.; Kashan, I.A.; Malau-Aduli, A. Spirulina supplementation, sire breed, sex and basal diet effects on lamb intramuscular fat percentage and fat melting points. Int. J. Vet. Med. 2014, 2014, 1-9. [CrossRef] 
44. Flakemore, A.R.; Balogun, R.O.; McEvoy, P.D.; Malau-Aduli, B.S.; Nichols, P.; Malau-Aduli, A.E.O. Genetic variation in intramuscular fat of prime lambs supplemented with varying concentrations of degummed crude canola oil. Int. J. Nutr. Food Sci. 2014, 3, 203-209. [CrossRef]

45. Malau-Aduli, A.; Holman, B.; Kashani, A.; Nichols, P. Sire breed and sex effects on the fatty acid composition and content of heart, kidney, liver, adipose and muscle tissues of purebred and first-cross prime lambs. Anim. Prod. Sci. 2016, 56, 2122-2132. [CrossRef]

46. Bligh, E.G.; Dyer, W.J. A rapid method of total lipid extraction and purification. Can. J. Biochem. Phys. 1959, 37, 911-917. [CrossRef] [PubMed]

47. Miller, M.R.; Nichols, P.D.; Barnes, J.; Davies, N.W.; Peacock, E.J.; Carter, C.G. Regiospecificity profiles of storage and membrane lipids from the gill and muscle tissue of atlantic salmon (Salmo salar L.) grown at elevated temperature. Lipids 2006, 41, 865-876. [CrossRef] [PubMed]

48. Clayton, E. Graham Centre Monograph no. 4: Long-Chain Omega-3 Polyunsaturated Fatty Acids in Ruminant Nutrition: Benefits to Animals and Humans; Nugent, T., Nicholls, C., Eds.; Charles Sturt University: Wagga-Wagga, Australia, 2014.

49. SAS. Statistical Analysis System. SAS/STAT User's Guide: Statistics; Version 9.4.; SAS Inc.: Cary, NC, USA, 2013.

50. Font-i-Furnols, M.; Guerrero, L. Consumer preference, behavior and perception about meat and meat products: An overview. Meat Sci. 2014, 98, 361-371. [CrossRef]

51. de Andrade, J.C.; de Aguiar Sobral, L.; Ares, G.; Deliza, R. Understanding consumers' perception of lamb meat using free word association. Meat Sci. 2016, 117, 68-74. [CrossRef]

52. Sañudo, C.; Alfonso, M.; Sanchez, A.; Berge, P.; Dransfield, E.; Zygoyiannis, D.; Stamataris, C.; Thorkelsson, G.; Valdimarsdottir, T.; Piasentier, E.; et al. Meat texture of lambs from different European production systems. Aust. J. Agric. Res. 2003, 54, 551-560. [CrossRef]

53. Young, O.A.; Lane, G.A.; Priolo, A.; Fraser, K. Pastoral and species flavour in lambs raised on pasture, lucerne or maize. J. Sci. Food Agric. 2003, 83, 93-104. [CrossRef]

54. Young, O.A.; Berdagué, J.L.; Viallon, C.; Rousset-Akrim, S.; Theriez, M. Fat-borne volatiles and sheepmeat odour. Meat Sci. 1997, 45, 183-200. [CrossRef]

55. Young, O.A.; Lane, G.A.; Podmore, C.; Fraser, K.; Agnew, M.J.; Cummings, T.L.; Cox, N.R. Changes in composition and quality characteristics of ovine meat and fat from castrates and rams aged to 2 years. N. Z. J. Agric. Res. 2006, 49, 419-430. [CrossRef]

56. Priolo, A.; Micol, D.; Agabriel, J. Effects of grass feeding systems on ruminant meat colour and flavour. A review. Anim. Res. 2001, 50, 185-200. [CrossRef]

57. Watkins, P.J.; Frank, D.; Singh, T.K.; Young, O.A.; Warner, R.D. Sheepmeat flavor and the effect of different feeding systems: A review. J. Agric. Food Chem. 2013, 61, 3561-3579. [CrossRef] [PubMed]

58. Watkins, P.J.; Kearney, G.; Rose, G.; Allen, D.; Ball, A.J.; Pethick, D.W.; Warner, R.D. Effect of branched-chain fatty acids, 3-methylindole and 4-methylphenol on consumer sensory scores of grilled lamb meat. Meat Sci. 2014, 96, 1088-1094. [CrossRef] [PubMed]

59. Watkins, P.J.; Rose, G.; Salvatore, L.; Allen, D.; Tucman, D.; Warner, R.D.; Dunshea, F.R.; Pethick, D.W. Age and nutrition influence the concentrations of three branched chain fatty acids in sheep fat from Australian abattoirs. Meat Sci. 2010, 86, 594-599. [CrossRef] [PubMed]

60. Bekhit, A.E.D.A.; Hopkins, D.L.; Fahri, F.T.; Ponnampalam, E.N. Oxidative processes in muscle systems and fresh meat: Sources, markers, and remedies. Compr. Rev. Food Sci. Food Saf. 2013, 12, 565-597. [CrossRef]

61. Daley, C.A.; Abbott, A.; Doyle, P.S.; Nader, G.A.; Larson, S. A review of fatty acid profiles and antioxidant content in grass-fed and grain-fed beef. Nutr. J. 2010, 9, 10. [CrossRef] [PubMed]

62. Van Elswyk, M.E.; McNeill, S.H. Impact of grass/forage feeding versus grain finishing on beef nutrients and sensory quality: The US experience. Meat Sci. 2014, 96, 535-540. [CrossRef]

63. Zervas, G.; Tsiplakou, E. The effect of feeding systems on the characteristics of products from small ruminants. Small Rum. Res. 2011, 101, 140-149. [CrossRef]

64. Baldi, G.; Chauhan, S.S.; Linden, N.; Dunshea, F.R.; Hopkins, D.L.; Sgoifo Rossi, C.A.; Dell'Orto, V.; Ponnampalam, E.N. Comparison of a grain-based diet supplemented with synthetic vitamin E versus a lucerne (alfalfa) hay-based diet fed to lambs in terms of carcass traits, muscle vitamin E, fatty acid content, lipid oxidation, and retail colour of meat. Meat Sci. 2019, 148, 105-112. [CrossRef] 
65. Malau-Aduli, A.E.O.; Kashani, A. Molecular genetics-nutrition interactions in the expression of AANAT, ADRB3, BTG2 and FASN genes in the heart, kidney and liver of Australian lambs supplemented with Spirulina (Arthrospira platensis). Genes Genom. 2015, 37, 633-644. [CrossRef]

66. Smith, S.B.; Yang, A.; Larsen, T.W.; Tume, R.K. Positional analysis of triacylglycerols from bovine adipose tissue lipids varying in degree of unsaturation. Lipids 1998, 33, 197-207. [CrossRef]

67. Cafferky, J.; Hamill, R.M.; Allen, P.; O'Doherty, J.V.; Cromie, A.; Sweeney, T. Effect of breed and gender on meat quality of M. longissimus thoracis et lumborum muscle from crossbred beef bulls and steers. Foods 2019, 8, 173. [CrossRef] [PubMed]

68. Venkata Reddy, B.; Sivakumar, A.S.; Jeong, D.W.; Woo, Y.B.; Park, S.J.; Lee, S.Y.; Hwang, I. Beef quality traits of heifer in comparison with steer, bull and cow at various feeding environments. Anim. Sci. J. 2015, 86, 1-16. [CrossRef] [PubMed]

69. Hopkins, D.L.; Mortimer, S.I. Effect of genotype, gender and age on sheep meat quality and a case study illustrating integration of knowledge. Meat Sci. 2014, 98, 544-555. [CrossRef] [PubMed]

70. Pannier, L.; Pethick, D.; Geesink, G.; Ball, A.; Jacob, R.; Gardner, G. Intramuscular fat in the longissimus muscle is reduced in lambs from sires selected for leanness. Meat Sci. 2014, 96, 1068-1075. [CrossRef]

71. Pannier, L.; Pethick, D.; Geesink, G.; Ball, A.; Jacob, R.; Gardner, G. Intramuscular fatty acid profile of feedlot lambs fed concentrates with alternative ingredients. Anim. Prod. Sci. 2019, 59, 914-920.

72. McPhee, M.; Oltjen, J.; Fadel, J.; Mayer, D.; Sainz, R. Parameter estimation and sensitivity analysis of fat deposition models in beef steers using acsIXtreme. Math. Comput. Simul. 2009, 79, 2701-2712. [CrossRef]

73. Okeudo, N.; Moss, B. Intramuscular lipid and fatty acid profile of sheep comprising four sex-types and seven slaughter weights produced following commercial procedure. Meat Sci. 2007, 76, 195-200. [CrossRef]

74. Lee, H.K.; Lee, J.K.; Cho, B. The role of androgen in the adipose tissue of males. World J. Mens. Health 2013, 31, 136. [CrossRef]

75. Xu, X.; De Pergola, G.; Björntorp, P. The effects of androgens on the regulation of lipolysis in adipose precursor cells. Endocrinol 1990, 126, 1229-1234. [CrossRef]

76. Bong, J.J.; Jeong, J.Y.; Rajasekar, P.; Cho, Y.M.; Kwon, E.G.; Kim, H.C.; Baik, M. Differential expression of genes associated with lipid metabolism in longissimus dorsi of Korean bulls and steers. Meat Sci. 2012, 91, 284-293. [CrossRef]

77. Bong, J.J.; Jeong, J.Y.; Rajasekar, P.; Cho, Y.M.; Kwon, E.G.; Kim, H.C.; Paek, B.H.; Baik, M. Impact of inbreeding on milk fatty acids of a Brazilian Holstein cattle. Anim. Prod. Sci. 2020, 60, 1482-1490.

78. Zárate, R.; El Jaber-Vazdekis, N.; Tejera, N.; Pérez, J.; Rodriguez, C. Significance of long chain polyunsaturated fatty acids in human health. Clin. Transl. Med. 2017, 6, 25. [CrossRef] [PubMed]

79. Gould, J.F.; Smithers, L.G.; Makrides, M. The effect of maternal omega-3 (n-3) LCPUFA supplementation during pregnancy on early childhood cognitive and visual development: A systematic review and meta-analysis of randomized controlled trials. Am. J. Clin. Nutr. 2013, 97, 531-544. [CrossRef] [PubMed]

80. Le, H.V.; Nguyen, D.V.; Nguyen, Q.V.; Malau-Aduli, B.S.; Nichols, P.D.; Malau-Aduli, A.E.O. Fatty acid profiles of muscle, liver, heart and kidney of Australian prime lambs fed different polyunsaturated fatty acids enriched pellets in a feedlot system. Sci. Rep. 2019, 9, 1-11.

81. Lourenço, M.; Van Ranst, G.; Vlaeminck, B.; De Smet, S.; Fievez, V. Influence of different dietary forages on the fatty acid composition of rumen digesta as well as ruminant meat and milk. Anim. Feed Sci. Technol. 2008, 145, 418-437. [CrossRef]

82. Ponnampalam, E.N.; Butler, K.L.; Jacob, R.H.; Pethick, D.W.; Ball, A.J.; Hocking-Edward, J.E.; Geesink, G.; Hopkins, D.L. Health beneficial long chain omega-3 fatty acid levels in Australian lamb managed under extensive finishing systems. Meat Sci. 2014, 96, 1104-1110. [CrossRef]

83. Ponnampalam, E.N.; Dunshea, F.R.; Warner, R.D. Use of lucerne hay in ruminant feeds to improve animal productivity, meat nutritional value and meat preservation under a more variable climate. Meat Sci. 2020, 170, 108235. [CrossRef]

84. Ponnampalam, E.N.; Pearce, K.M.; Mortimer, S.I.; Pethick, D.W.; Ball, A.J.; Hopkins, D.L. Sources of variation of health claimable long chain omega-3 fatty acids in meat from Australian lamb slaughtered at similar weights. Meat Sci. 2014, 96, 1095-1103. [CrossRef]

85. Ponnampalam, E.N.; Sinclair, A.J.; Egan, E.R.; Ferrier, G.R.; Leury, B.J. Dietary manipulation of muscle long-chain omega-3 and omega-6 fatty acids and sensory properties of lamb meat. Meat Sci. 2002, 60, 125-132. [CrossRef] 
86. Ponnampalam, E.N.; Trout, G.R.; Sinclair, A.J.; Egan, E.R.; Leury, B.J. Comparison of the color stability and lipid oxidative stability of fresh and vacuum packaged lamb muscle containing elevated omega- 3 and omega-6 fatty acid levels from dietary manipulation. Meat Sci. 2001, 58, 151-161. [CrossRef]

87. Flakemore, A.R.; Malau-Aduli, B.S.; Nichols, P.D.; Malau-Aduli, A.E.O. Omega-3 fatty acids, nutrient retention values, and sensory meat eating quality in cooked and raw Australian lamb. Meat Sci. 2017, 123, 79-87. [CrossRef] [PubMed]

88. Knight, M.I.; Daetwyler, H.D.; Hayes, B.J.; Hayden, M.J.; Ball, A.J.; Pethick, D.W.; McDonagh, M.B. An independent validation association study of carcass quality, shear force, intramuscular fat percentage and omega-3 polyunsaturated fatty acid content with gene markers in Australian lamb. Meat Sci. 2014, 96, 1025-1033. [CrossRef] [PubMed]

89. Knight, M.I.; Butler, K.L.; Linden, N.P.; Burnett, V.F.; Ball, A.J.; McDonagh, M.B.; Behrendt, R. Understanding the impact of sire lean meat yield breeding value on carcass composition, meat quality, nutrient and mineral content of Australian lamb. Meat Sci. 2020, 170, 108236. [CrossRef] [PubMed]

90. De Brito, G.F.; Holman, B.W.B.; McGrath, S.R.; Friend, M.A.; van de Ven, R.; Hopkins, D.L. The effect of forage-types on the fatty acid profile, lipid and protein oxidation and retail colour stability of muscles from White Dorper lambs. Meat Sci. 2017, 130, 81-90. [CrossRef] [PubMed]

91. Fowler, S.M.; Morris, S.; Hopkins, D.L. Nutritional composition of lamb retail cuts from the carcasses of extensively finished lambs. Meat Sci. 2019, 154, 126-132. [CrossRef] [PubMed]

Publisher's Note: MDPI stays neutral with regard to jurisdictional claims in published maps and institutional affiliations. 